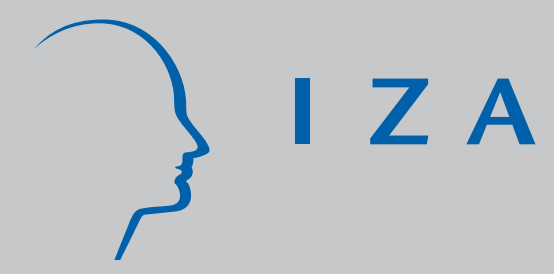

IZA DP No. 3927

India's Approach to Capital Account Liberalization

Eswar S. Prasad

J anuary 2009 


\title{
India's Approach to Capital Account Liberalization
}

\author{
Eswar S. Prasad \\ Cornell University, Brookings Institution, \\ NBER and IZA
}

Discussion Paper No. 3927

January 2009

\author{
IZA \\ P.O. Box 7240 \\ 53072 Bonn \\ Germany \\ Phone: +49-228-3894-0 \\ Fax: +49-228-3894-180 \\ E-mail: iza@iza.org
}

Any opinions expressed here are those of the author(s) and not those of IZA. Research published in this series may include views on policy, but the institute itself takes no institutional policy positions.

The Institute for the Study of Labor (IZA) in Bonn is a local and virtual international research center and a place of communication between science, politics and business. IZA is an independent nonprofit organization supported by Deutsche Post World Net. The center is associated with the University of Bonn and offers a stimulating research environment through its international network, workshops and conferences, data service, project support, research visits and doctoral program. IZA engages in (i) original and internationally competitive research in all fields of labor economics, (ii) development of policy concepts, and (iii) dissemination of research results and concepts to the interested public.

IZA Discussion Papers often represent preliminary work and are circulated to encourage discussion. Citation of such a paper should account for its provisional character. A revised version may be available directly from the author. 


\section{ABSTRACT}

\section{India's Approach to Capital Account Liberalization ${ }^{*}$}

In this paper, I analyze India's approach to capital account liberalization through the lens of the new literature on financial globalization. India's authorities have taken a cautious and calibrated path to capital account opening, which has served the economy well in terms of reducing its vulnerability to crises. By now, the capital account has become quite open and reversing this is not a viable option. Moreover, the remaining capital controls are rapidly becoming ineffective, making the debate about capital controls rather moot. Managing de facto financial integration into international capital markets and aligning domestic macroeconomic policies in a manner that maximizes the indirect benefits and reduces the risks is the key challenge now facing India's policymakers on this front.

JEL Classification: F3, F4, O2

Keywords: India, international financial integration, capital flows, capital controls

Corresponding author:

Eswar S. Prasad

Department of Applied Economics and Management

Cornell University

440 Warren Hall

Ithaca, NY 14853

USA

E-mail: eswar.prasad@cornell.edu

\footnotetext{
*I thank the participants at the Brookings-NCAER India Policy Forum, and especially the discussants for this paper, John Williamson and Partha Sen, for their helpful comments. I am grateful to Arvind Panagariya for his detailed and constructive comments, which have greatly improved the paper. Rahul Anand provided excellent research assistance on this paper. I also thank Vinay DCosta for help with gathering and interpreting data on India's capital controls.
} 


\section{Introduction}

Capital account liberalization remains a highly contentious issue. Proponents argue that it fosters financial globalization - a term that broadly encompasses cross-border flows of financial capital in various forms. This phenomenon, in principle, should allow for a more efficient allocation of financial resources across countries and also permit countries to share their country-specific income risk more efficiently, thereby increasing economic welfare on both counts. Detractors have blamed capital account liberalization as being the root cause of the financial crises experienced by many countries and argue that the deck is particularly stacked against non-industrial countries, which have experienced few benefits but exposed themselves to considerable risks (see, e.g., Bhagwati, 1998; Rodrik, 1998).

The polemics on both sides are again becoming heated as emerging market economies and even some low-income countries are having to cope with volatile capital inflows, even as major economies like China and India are contemplating further opening of their capital accounts. Meanwhile, there have recently been important advances in the academic literature. This is causing researchers to take a more nuanced approach to the issue and to frame the debate in terms of a complex set of cost-benefit tradeoffs. One of the key conclusions of the new literature is that the principal benefit of financial openness for developing economies may not be access to foreign capital that helps increase domestic investment by relaxing the constraint imposed by a low level of domestic saving. Rather, the main benefits may be indirect ones associated with openness to foreign capital, including the catalytic effects of foreign finance on domestic financial market development, enhanced discipline on macroeconomic policies, and improvements in corporate governance as well as other aspects of institutional quality.

A major complication, however, is that economies that have weak initial conditions in certain dimensions seem to have much worse outcomes from their integration into international financial markets, in terms of both lower benefits and higher risks. For countries below these "threshold" conditions, the benefit-risk tradeoff becomes complicated and a one-shot approach to capital account liberalization may be risky and 
counter-productive. Some of these threshold conditions (e.g., level of financial development, quality of domestic institutions) are similar to the list of indirect benefits, pointing to a difficult tension faced by low- and middle-income countries that want to use financial openness as a catalyst for those benefits but would then face the risks associated with being below the threshold conditions.

At the same time, the practical reality is that emerging market countries are having to adapt to rising financial globalization. Capital controls are being rendered increasingly ineffective by the rising sophistication of international investors, the sheer quantity of money flowing across national borders, and the increasing number of channels (especially expanding trade flows) for the evasion of these controls. Hence, emerging market economies like China and India are perforce grappling with the new realities of financial globalization, wherein capital controls are losing their potency as a policy instrument (or at least as an instrument that creates more room for monetary and other macro policies).

Developments in international financial markets also have a bearing on this issue. In recent years, emerging markets had been getting more capital inflows than they could comfortably handle, causing complications for domestic macroeconomic policies and also exposing these economies even more to the volatility of foreign capital. International investors, especially from industrial economies, had turned up in droves at the shores of emerging markets in recent years but are now retreating due to the recent global financial turmoil. It is likely that, once financial markets settle down, they will again be lured by the strong growth prospects of many emerging markets as well as weak growth and low interest rates in their home countries. The same forces are also likely to cause domestic investors in emerging markets to resume repatriation of their capital from abroad.

Against this background, the objective of this paper is to provide a critical analysis of India's approach to capital account liberalization program through the lens of the new literature on financial globalization (Bhagwati's essay presages many of the ideas being developed in this literature). In recent years, the Reserve Bank of India (RBI) has taken what it calls a calibrated approach to capital account liberalization, with certain types of 
flows and particular classes of economic agents being prioritized in the process of liberalization (see Reddy, 2007). I will evaluate the effectiveness of this approach in terms of the narrow objectives of influencing the quantity and composition of flows, and also in terms of macroeconomic consequences. This will involve an empirical characterization of the evolution of financial openness based on de jure measures of capital account openness as well as de facto measures of financial integration. I will also examine the evolution and structure of inflows and outflows. I will then relate these to the literature on the determinants and effects of external capital structure.

The cautious and calibrated approach has meant that India's capital account liberalization has proceeded in fits and starts but the net effect is that, over time, the capital account has become increasingly open and India has been rapidly integrating into international capital markets. While this approach has to some extent helped protect the country from the volatility induced by financial flows, a key question is whether this approach may have subtle costs in terms of efficiency and welfare that outweigh this benefit.

The main thesis of this paper is that, at this juncture, a more reasonable policy approach is to accept rising financial openness as a reality and manage, rather than resist (or even try to reverse), the process of fully liberalizing capital account transactions. Dealing with and benefiting from the reality of an open capital account will require improvements in other policies - especially monetary, fiscal and financial sector regulatory policies. This approach could in fact substantially improve the indirect benefits to be gleaned from integration into international financial markets.

This line of reasoning does not mean that capital account liberalization should be a key policy priority and that the remaining restrictions on the capital account should be dropped at one fell swoop. But it does imply that there are some subtle risks and welfare consequences that can arise from holding monetary and exchange rate policies as well as financial sector reforms hostage to the notion that the capital account should be kept relatively restricted for as long as possible. It may seem reasonable to maintain whatever capital controls still exist in order to get at least some protection from the vagaries of 
international capital flows. Not only is this not a realistic proposition, but I will also argue that it could detract from many of the potential indirect benefits of financial integration. In summary, steady progress towards a more open capital account may be the most pragmatic policy strategy.

In the next section, I provide an overview of the new literature on the benefits and risks of financial globalization. In Section III, I describe the evolution of India's financial openness based on a wide range of indicators. In the subsequent three sections, I provide a detailed analysis of the structure of and changes in India's balance of payments, cross-border financial flows, and international reserves. In the final section of the paper, I discuss the implications of India's approach towards capital account liberalization for monetary and exchange rate policies and for financial sector reforms. While full capital account liberalization is hardly an end in itself, it can provide a useful framework for setting in motion a broader set of macroeconomic reforms.

\section{Paradoxical Results, But Composition of Liabilities Matters}

Despite the strong theoretical presumption that financial openness should boost growth in developing countries, macroeconomic evidence of the growth benefits of financial openness remains elusive (see Kose et al., 2006; Kletzer IPF 2005 for surveys). Although there is a positive correlation between measures of financial openness and growth, this correlation vanishes once one controls for other determinants of growth such as financial development, quality of institutions, and macroeconomic policies. More recent evidence based on better measures of de facto financial openness or specific types of liberalization (such as equity market liberalizations) does show more positive effects. Analysis based on industry- or firm-level data is also more supportive of the efficiency and growth benefits of financial globalization. But this evidence is hardly conclusive.

Indeed, there is some remarkable new evidence that non-industrial countries that rely less on foreign capital have on average posted better long-run growth outcomes (see Aizenman, Pinto and Radziwill, 2008; Gourinchas and Jeanne, 2007; Prasad, Rajan and Subramanian, 
2007). This result is not just limited to the recent period of rising global imbalances, when some fast-growing economies like China have on net been exporting massive amounts of capital. This result holds up over much longer periods of time and is not specific to countries in any particular region. Rodrik (2008) interprets these new findings as suggesting that the real constraint to growth in many less-developed economies is investment not savings. Ineffectual financial systems may not be up to the task of efficiently intermediating domestic savings into investment, let alone being able to intermediate foreign capital efficiently.

Given these empirical findings, a new paradigm is emerging that the main benefits of financial globalization may not be through the direct channel of providing more financing. Rather, the main benefits may be in terms of catalyzing financial market and institutional development, stimulating gains in efficiency through competition and access to new technologies, and disciplining macroeconomic policies (see Schematic 1). There is accumulating evidence for this paradigm, although it is by no means conclusive yet. ${ }^{1}$ Nevertheless, this paradigm has important implications for empirical analysis of the effects of capital account liberalization and also for designing such liberalization programs.

A complication, however, is that there appear to be some threshold conditions that influence the cost-benefit tradeoff. Indeed, factors such as financial market development and the quality of institutions also seem to play a crucial role in determining the extent of benefits a country can derive from financial openness and also how vulnerable it is to the risks associated with capital flows. These thresholds are considerably lower for certain types of financial flows - FDI and portfolio equity, in particular — and higher for debt

\footnotetext{
${ }^{1}$ Kose et al. (2006) develop this framework and survey the evidence on each of these potential indirect (or "collateral") benefits. There is a growing body of evidence-based on country case studies as well as cross-country analysis using both macroeconomic and microeconomic (firm- and sector-level) data - that financial openness tends to positively influence financial development and institutional quality. The evidence that it boosts macroeconomic discipline remains sparse, however. For skeptical views about the notion that financial integration delivers such indirect benefits, see Eichengreen (2007) and Rodrik and Subramanian (2008).
} 
inflows. ${ }^{2}$ Indeed, there are many examples of how underdeveloped or poorly regulated financial markets and weak institutions can interact in ways that result in misallocation of foreign capital and make countries vulnerable to financial crises. ${ }^{3}$

This framework clearly highlights some deep tensions in the process of capital account liberalization that cannot easily be avoided. But the collateral benefits-thresholds framework also suggests a way forward. If one can prioritize the indirect "collateral" benefits that a country needs, it should in principle be possible to undertake a controlled capital account liberalization that helps attain these benefits while reducing the risks. Thus, the framework encompasses a general approach that can still take account of countryspecific circumstances and initial conditions. For instance, Prasad and Rajan (2008) propose a method for countries experiencing sustained large inflows to securitize their reserve accumulation. This would, in a controlled way, help balance the inflows by encouraging outflows, and would deliver the indirect benefits of broadening financial markets and allowing citizens of these countries to benefit from international portfolio diversification.

\section{Risk sharing}

It is also worth considering other potential benefits of financial openness rather than just its effects on GDP growth. One of the main presumed benefits of international financial integration is that it should facilitate international trade in financial assets, thereby enabling countries to diversify away their income risk and thereby smooth their consumption growth. Remarkably, the evidence shows that financial integration has, on average, led to worse risk sharing outcomes for emerging market economies during the period of

\footnotetext{
${ }^{2}$ Kose, Prasad and Taylor (2008) review the theoretical basis for such threshold effects and provide some quantitative evidence that thresholds matter, even though it proves difficult to pin down precisely the exact levels of various thresholds. Mukerji (2009) provides evidence that higher levels of financial development and stable macroeconomic policies enable countries to gain modest growth benefits from capital account convertibility, while weak financial systems and macroeconomic vulnerabilities increase growth instability without raising average growth.

${ }^{3}$ See Krueger and Yoo (2002) and Desai (2003) for interesting narrative accounts.
} 
globalization. Only industrial countries have been able to more efficiently share risk through the process of financial integration. Kose, Prasad and Terrones (2007) document these patterns in the data. They also probe more deeply into why financial integration seems to hurt emerging markets on this dimension.

They find that stocks of FDI and portfolio equity liabilities are in fact associated with better risk sharing outcomes while stocks of external debt liabilities are not. Indeed, this goes a long way towards explaining the paradoxical outcomes for emerging markets. Until recently, financial integration for these economies largely took place in the form of debt accumulation. Not only are debt flows themselves procyclical, interest payments on external debt are typically not indexed to the business cycle, so they have a procyclical element to them as well. FDI and portfolio equity flows by their very nature involve a sharing of risk between foreign investors and their host countries. They have also tended to be more stable than debt flows. Interestingly, advanced economies do not seem to suffer similar problems from debt flows, which still dominate cross-border flows among these economies. This could be because they have better-developed financial markets and, typically, more flexible exchange rates, both of which act as shock absorbers in the face of capital flow volatility.

\section{Productivity growth}

The literature about the indirect benefits of financial integration emphasizes that the main benefits of financial integration are in terms of TFP growth. Interestingly, while there has been a vast literature examining the effects of integration on output growth, scant attention has been paid to its effects on TFP growth. In a recent contribution, Kose, Prasad and Terrones (2008) find that de jure capital account openness is positively associated with TFP growth. Surprisingly, however, overall de facto financial integration is not correlated with TFP growth. This turns out to mask a novel and interesting result. FDI and portfolio equity liabilities are in fact associated with much higher productivity growth, while stocks of debt liabilities are negatively correlated with TFP growth, especially in economies with underdeveloped financial systems. What explains this difference? The indirect "collateral" 
benefits of financial flows tend to flow from FDI, in terms of technological and skill spillovers, and from portfolio equity, in the form of increased depth and innovations in equity markets. Financial sector FDI has also been found to help in the import of good governance practices and financial innovations (Goldberg, 2004).

A common theme that emerges from this new literature is that, in terms of evaluating the potential benefits and risks of financial integration, the composition of the stock of external liabilities is highly relevant in a number of dimensions. This is of course not a big surprise - for instance, it is in line with the earlier literature on sequencing of capital account liberalization. But it is nevertheless comforting that some of the theoretical predictions about the benefits of financial integration can be recovered with a suitable disaggregation of the data.

This brief overview of the new literature on the benefits and costs of financial openness will help us in understanding the implications of India's rising financial openness. To begin with, we need to know how open India's capital account actually is.

\section{How Open is India's Capital Account}

The traditional approach to measuring financial openness is to use measures of legal restrictions on cross-border capital flows. The conventional binary indicator of capital account openness is based on information contained in the International Monetary Fund's Annual Report on Exchange Arrangements and Exchange Restrictions (AREAER) for each of the IMF's member countries (Schindler, 2007). Authors such as Miniane (2004), Chinn and Ito (2006), and Edwards (2007) have developed finer measures of capital account openness using disaggregated information from the AREAER. ${ }^{4}$

\footnotetext{
${ }^{4}$ See Mohan (2008, Annex 1) for a comprehensive listing of capital controls still in place in India.
} 
An alternative approach is to use a de facto measure that tries to take into account how much a country is integrated into international capital markets in practice. ${ }^{5}$ A measure of gross flows as a ratio to GDP captures two-way flows, which one would expect to see if economies were in fact sharing risk efficiently in a world with multiple financial instruments and agents with different risk profiles. Using the sum of gross inflows and outflows as a ratio to national GDP also yields a nice symmetry with the widely-used measure of trade openness, which is the sum of imports and exports as a ratio to GDP.

However, such annual flows tend to be quite volatile and are prone to measurement error. To mitigate (but obviously not eliminate) these problems, Kose et al. (2008) propose using the sum of gross stocks of foreign assets and liabilities as a ratio to GDP. For some purposes--particularly risk sharing--the stock measures are more appropriate. For instance, if countries have large gross stocks of assets and liabilities, small exchange rate changes can have large valuation effects and serve as a mechanism for risk-sharing even if net asset positions are small. For emerging market countries, another relevant measure of de facto financial integration is the ratio of gross stocks of external liabilities to GDP - a cumulated measure of inflows that is most closely related to the notion of openness to foreign capital that could be associated with technological and other spillovers. We take these measures of de facto financial integration from the widely-used database created by Lane and MilesiFerretti (2006).

There is important information in both the de jure and de facto measures. De jure measures are relevant for analysis of the effects of capital account liberalization policies. But the existence of capital controls often does not accurately capture an economy's actual level of integration into international financial markets. These measures do not capture the degree of enforcement of capital controls (or the effectiveness of that enforcement), which can change over time even if the legal restrictions themselves remain unchanged. Many

\footnotetext{
${ }^{5}$ Another approach has been to look at price-based measures of asset market integration. However, there are serious practical problems in using such measures for developing economies. Returns on financial instruments in those economies may incorporate a multitude of risk and liquidity premia that are difficult to disentangle. Even interest parity conditions sometimes do not hold because of inefficiencies and lack of depth in some of these markets.
} 
countries with extensive capital controls have still experienced massive outflows of private capital, while some economies with open capital accounts have recorded few capital inflows or outflows. For instance, despite its extensive regime of capital controls, China has not been able to block inflows of speculative capital in recent years (Prasad and Wei, 2007). A further complication is that, despite the extensive coverage of the IMF's annual AREAER publication, there could be other regulations that effectively act as capital controls but are not counted as controls. For instance, prudential regulations that limit the foreign exchange exposure of domestic banks could, under certain circumstances, have the same effect as capital controls.

The de facto measure may be conceptually more appropriate to the extent that one is interested in the effects of an outcome-based measure of financial integration. On the other hand, many of the indirect benefits of financial integration may be vitiated by the presence of capital controls. Efficiency gains from competition, technology transfers, spillovers of good corporate and public governance practices etc. may be associated with an open capital account. Inward flows that manage to circumvent capital account restrictions are much less likely to convey many of the indirect benefits of financial integration. Many authors have also pointed out that capital controls can impose significant distortionary costs at the microeconomic (firm or industry) level, even if economic agents find ways to evade those controls (see the survey by Forbes, 2005).

How does India stack up on these different measures of financial openness? Table 1 presents some summary statistics on each of the measures of de jure capital account openness discussed above at different points of time. For each measure and each date, the table shows the median value for the full sample of countries, different values for emerging market countries, and the value assigned to India. By any of these measures, it looks like India is at the low end of the distribution of the respective capital account openness measure in 1995. There is a trend increase over time in average capital account openness for the full sample of countries. By 2005, India remains near the bottom of the distribution 
of Chinn-Ito measures but moves up significantly per the Edwards measure. ${ }^{6}$ These are all relatively crude measures of de jure openness, based on a reading of the IMF's annual AREAER reports on each country. But in India's case they do signal that there are some restrictions on capital account transactions even in categories of flows that have been liberalized (even minimal registration requirements do get counted as restrictions).

More substantively, the RBI has in fact eased a number of controls, both on inflows and outflows. For instance, although capital outflows by individuals are in principle still restricted, each individual is allowed to take up to $\$ 200,000$ of capital out of India each year, a generous ceiling by any standards. ${ }^{7}$ The restrictions on outflows by Indian corporates are even weaker. As for inflows, FDI inflows into certain sectors such as retail and banking are restricted, and foreign investors are not allowed to participate in the government debt market. These restrictions are gradually being lifted. Equity market investments are permitted by registered foreign institutional investors (although there are limits on their ownership shares in certain types of Indian firms), and those who do not wish to register can invest only indirectly through an instrument called participatory notes, which are tightly regulated by the government.

We now turn to India's de facto integration with international capital markets. Figure 1 shows that gross external liabilities, gross external assets, and the sum of these two variables (expressed as ratios to GDP) have all increased significantly in recent years, indicative of the rapid pace at which India has been integrating into international capital markets. From 1980 to the mid-1990s, the total integration measure rose by about 25 percentage points, with almost this entire increase accounted for by an increase in external

\footnotetext{
${ }^{6}$ A different measure of de jure capital account openness is the equity market liberalization indicator created and used by Bekaert and Harvey (2000) and Henry (2000). This is considered a one-off liberalization that occurs when domestic equity markets are opened up to foreign investors. These authors list India as having liberalized its equity markets in 1992 (and China as having done so in 1994).

${ }^{7}$ There are a few minor and relatively innocuous restrictions on these outflows (e.g., money cannot be taken abroad without RBI permission for margin calls; to a small group of neighboring countries; and to countries identified as not cooperating with international anti-money laundering regulations).
} 
liabilities. In the mid-1980s, especially with the onset of the Asian financial crisis, de facto integration leveled off, although it is interesting to note that foreign assets continued to increase gradually during this period. From 2000 to 2006, the integration measure shot up by nearly 26 percentage points, with accumulation of external liabilities and assets accounting in almost equal part for this increase.

Nevertheless, on a cross-country comparison and relative to its size, India appears to have one of the least financially open economies amongst the group of emerging markets. Figure 2 shows that India was near the bottom of the distribution of the preferred de facto integration measure; its relative position among emerging markets remains quite stable despite the rapid increase in its absolute level of integration. Thus, in terms of both de jure and de facto measures, India's low level of financial openness puts it well below the levels attained by most other emerging market economies, including the other large BRIC economies - Brazil, China and Russia. This perspective is useful to keep in mind while discussing whether India has exposed itself to considerable risks from rapid integration into international capital markets.

\section{The Balance of Payments}

In order to dissect the forces behind the accumulation of foreign assets and liabilities, we now turn to an analysis of the underlying flows. India's engagement with the world economy through both trade and financial linkages can best be seen through the prism of the balance of payments. There have been dramatic changes in the evolution of India's balance of payments since the currency crisis of the early 1990s (Table 2). During and right after the period of the Asian financial crisis, the current account and capital account roughly balanced each other. In the early part of this decade, the current account balance turned slightly positive, despite a trade deficit. Indeed, this has been a consistent story in India during this decade - that the trade deficit has been offset to a considerable extent by a surplus on invisibles trade and remittances from Indian workers abroad. 
Reserve accumulation gradually picked up speed during the early 2000s. There has been a marked shift in the structure of the balance of payments during the last two years (2006-07 and 2007-08). The merchandise trade deficit has risen sharply (to 8 percent of GDP) and the current account deficit is now 1.5 percent of GDP, both larger than at any other time during the past decade. But large capital inflows have more than offset the current account deficit, leading to rapid reserve accumulation.

At the end of financial year 2008, gross international reserves stood at $\$ 310$ billion, representing about 27 percent of nominal GDP. Figure 3 shows that reserve accumulation has hardly been a steady and unrelenting process in India (unlike in China, where it has). There were a number of months, even during this period of unprecedented reserve accumulation, when reserves actually fell. But the overall trend until the summer of 2008 was clearly one of not just a rising level of reserves but also a rising pace of reserve accumulation. The global financial turmoil that swept on to India's shores in September 2008 led to depreciation pressures on the rupee and the RBI has used up about $\$ 30$ billion of its stock of reserves to limit the depreciation of the rupee. It is too early to tell if the era of large capital inflows to India is past or if inflows will recover when the global financial system settles down.

It is instructive to break down the reserve buildup into its components to examine what factors can explain the increase in the rate of accumulation. For this exercise, I split the nine-year period since the Asian financial crisis into three periods: 1998-99 to 2000-01; 2001-02 to 2005-06; and 2005-06 to 2007-08. For many Asian and other emerging market economies, the pace and sources of reserve accumulation differ markedly across these three periods (see, e.g., Prasad and Wei, 2007, for the case of China). The first three columns of Table 3 show the average annual increase in foreign exchange reserves during each of these periods and the breakdown of this increase into the main components. The next two columns show the changes in these averages across periods.

The rate of reserve accumulation was higher by an average of $\$ 17$ billion per year in the second period relative to the first. The current account balance shifted from an average 
deficit of $\$ 4$ billion per year in the first period to a surplus of $\$ 2$ billion per year in the second period, implying that the current account contributed about $\$ 6$ billion to the increase in the rate of reserve accumulation in the second period compared to the first. The change in the non-FDI capital account balance, which mainly constitutes portfolio flows, accounts for most of the remainder.

During 2006-08, the rate of reserve accumulation jumps by a further $\$ 57$ billion per year relative to the preceding period. The forces driving the reserve buildup in this period are very different from the previous period. The current account switches back into a deficit, resulting in a negative contribution of nearly $\$ 16$ billion per year from the current account. FDI and valuation changes account for $\$ 9$ billion and $\$ 13$ billion, respectively. The latter factor represents an increase in the dollar value of reserve assets held in currencies other than dollars as a consequence of the significant depreciation of the dollar against other major reserve currencies during this period. The big story during the last two years has clearly been the surge in portfolio inflows and various other debt inflows, which together meant that the non-FDI capital account balance contributed nearly $\$ 51$ billion per year to the faster pace of reserve accumulation during this period.

To better understand the implications of these patterns in the balance of payments, it is important to examine in more detail the structure of inflows and external liabilities.

\section{Composition of Gross Flows and External Liabilities}

I now provide a disaggregated perspective on India's de facto financial integration. As discussed in the review of the academic literature in Section II, the costs and benefits of financial openness are crucially dependent on the nature of financial integration. In this section, I review the composition of India's capital inflows and outflows, the structure of its external liabilities, and the implications for the benefit-cost trade-off. 


\section{V.1 Gross Flows}

Table 4 indicates that gross inflows have risen sharply since the early 2000s, from an average level of about 2 percent of GDP over the previous decade, to nearly 9 percent in 2007-08. The shares of the components of gross inflows fluctuate markedly from year to year and it is difficult to detect any clear trends over the full sample of data. Focusing on the last four years, it is clear that FDI and portfolio inflows have together become a major constituent of overall inflows. The trend in outflows, which still remain at very low levels (2 percent of GDP in 2007-08), is much clearer, with FDI accounting for the lions' share of outflows in recent years and portfolio flows barely registering on the scale.

\section{V.2 Composition of External Liabilities}

As discussed earlier, stocks of external liabilities are more reliable measures of the benefits that emerging markets can potentially attain from financial integration, and also the potential risks. For this part of the analysis, we turn again to the dataset of Lane and Milesi-Ferretti (2006). Figure 4 shows that the ratio of FDI and portfolio liabilities in gross external liabilities risen steadily, from a level below 10 percent in the early 1990 s to 60 percent at present. Based on the discussion in Section II about the relative merits of different forms of capital, this is clearly a positive development.

Figure 5, which provides a cross-country comparison of this ratio for emerging markets, shows that India is now in the middle of the pack and not too far off the level of the leading country. Indeed, India has moved up quite significantly from its position near the bottom of this cross-country distribution in 1995. It is also interesting to note that the dispersion of this ratio across emerging markets has decreased considerably over the past decade. This is of course consistent with other evidence that the composition of private capital flows to emerging markets has shifted markedly towards FDI and portfolio flows in recent years. ${ }^{8}$ Thus, in India, as in most other emerging markets, the structure of external

\footnotetext{
${ }^{8}$ Kose et al. (2006) report that, in 2000-04, debt accounted for about 52 percent of gross external liabilities of emerging markets, while FDI accounted for 37 percent. Portfolio equity liabilities
} 
liabilities has become quite favorable in terms of attaining the risk sharing and TFP growth benefits of financial openness.

\section{V.3 Structure of External Debt}

One component of foreign liabilities that is of particular interest is the stock of external debt. The size of the stock of short-term external debt denominated in foreign currencies has been identified as an important factor triggering many emerging market financial crises of the last two decades. Moreover, short-term debt flows tend to be highly procyclical and so do the financing terms for these flows (Kaminsky, Reinhart and Vegh, 2004).

Consequently, countries that rely to a great extent on short-term foreign-currency debt face a double whammy when they are hit with negative shocks and when external financing is in principle even more important to smooth domestic consumption.

India has taken a cautious approach to allowing the accumulation of foreign-currency denominated external debt, resulting in a low level of vulnerability on this front. The ratio of external debt to GDP has fallen from levels of around 38 percent in the early 1990s to under 20 percent in the last five years (see Table 5). The share of short-term debt in total external debt has risen to 20 percent, although this number should be interpreted with some caution as there appears to be a discontinuity in the split between short- and long-term debt in 2005. Between 2005 and 2008, the share of short-term debt in total debt has risen by nearly 7 percentage points, so the trend is clear at any rate.

With the opening up to capital inflows, the share of deposits by Indians who live abroad and other foreign currency deposits in total debt rose from 12 percent in the early 1990 s to 28 percent in 2004, before declining to 20 percent by 2008. External commercial borrowings by corporates have risen to about 28 percent of total debt, from about 12 percent in the early 1990s.

accounted for most of the remainder. Back in 1980-84, the corresponding shares for debt and FDI were 85 percent and 14 percent, respectively. 
Consider adding together three elements of the debt structure that could represent potential flight capital--foreign currency deposits, external commercial borrowings and short-term debt. If one adds all of these together, for 2007 the total amounts to about 13 percent of GDP. Some authors such as Williamson (2007) have expressed concerns that the liberalization of debt inflows may bode ill for India. The levels of debt are not high enough to warrant significant concern, although of course one could make the legitimate argument that this relatively benign outcome is because the government has limited external commercial borrowings and short-term debt. The problem is that it is now relatively straightforward to evade controls on this type of flow by bringing in capital as portfolio equity and swapping it for other instruments (including over-the-counter debt instruments).

In any event, the surge in external commercial borrowings does bear further consideration. Given the practically nonexistent domestic corporate debt market, firms interested in issuing debt may have been pushed to issue debt abroad. Moreover, the RBI's attempts to resist exchange rate appreciation during 2006-07 may in fact have created incentives for firms to seek capital abroad using debt denominated in foreign currencies. Firms may have been using this financing instrument to effectively place bets on an eventual currency appreciation. Thus, rather than viewing foreign debt as the problem to be dealt with, it would be more appropriate to think about aspects of the financial system and macro policies that may be creating incentives for firms to obtain financing through foreigncurrency debt. I will return to this theme in the concluding section.

\section{Does India Have Enough Reserves?}

In determining a country's vulnerability to external shocks, the structure of external assets and liabilities is an important indicator. I now examine the evolution of India's official international investment position (IIP) and its implications for India's financial openness. ${ }^{9}$

\footnotetext{
${ }^{9}$ Due to some differences in how valuation effects are computed for various components of external assets and liabilities, there are some discrepancies between the values of these stocks in the official IIP data and the Lane and Milesi-Ferretti (2006) dataset. These discrepancies have grown in the last few years as the stocks have increased, along with the magnitude of fluctuations
} 
The IIP effectively represents a country's balance sheet vis a vis the rest of the world. Table 6 shows that, at the end of financial year 2007-08, India had a net negative IIP position of $\$ 53$ billion. This represents a significant improvement from the level of minus $\$ 81$ billion in 1996-97, just before the Asian financial crisis. The stock of external assets has grown six-fold from $\$ 62$ billion in $2000-01$ to $\$ 381$ billion in 2007-08. A substantial portion of this stock is accounted for by reserves. At the end of FY 2007-08, the total stock of reserve assets was $\$ 310$ billion, of which foreign exchange reserves amounted to \$299 billion.

From an insurance perspective, the adequacy of the stock of foreign exchange reserves is typically measured relative to a country's imports or level of short-term external debt. Table 7 shows that, by both these measures, India has more than adequate reserves. Even as of 2007, reserves were sufficient to cover more than a year's worth of imports, well above the conventional threshold of six months of imports. Moreover, reserves even exceed the level of total external debt; recall that short-term debt is only 20 percent of external debt (Table 5), so reserves are many multiples of the level of short-term external debt.

From the perspective of capital account liberalization, an even more stringent criterion than the coverage of external debt is whether reserves cover a major portion of the stock of all non-FDI foreign liabilities, on the assumption that all liabilities other than FDI are relatively liquid and could fly out of a country at short notice. The IIP numbers show that, at the end of 2007-08, India's foreign exchange reserves (\$299 billion) were nearly adequate to cover its entire stock of non-FDI liabilities, which amounted to $\$ 318$ billion.

A different criterion suggested by some authors is whether reserves are sufficient to cover a significant portion of a broad monetary aggregate such as M2. ${ }^{10}$ Demand deposits and

in the value of the U.S. dollar. Hence, I use the official IIP data here but have used the Lane and Milesi-Ferretti in other sections to facilitate international comparisons.

${ }^{10}$ Obstfeld, Shambaugh and Taylor (2008) argue that concerns about domestic financial stability could be a key motive for the massive amount of reserve accumulation by emerging market 
currency can in principle flee a country at short notice; protecting the economy from the financial instability that could arise from such an event could be an important benchmark for policymakers to gauge a "safe" level of reserves. By this criterion, India, like many other emerging market economies (including China) does not have an excessively high level of reserves. The last column of Table 7 shows that India's reserves cover about 30 percent of an even broader aggregate M3. This is a large share but obviously not enough to offset a complete financial collapse and the accompanying loss of confidence in the domestic banking system. Given the relative prudence of the RBI and the large banks themselves, this seems a highly unlikely scenario. ${ }^{11}$

The basic conclusion of this section is that India has accumulated a level of foreign exchange reserves that exceeds most standard norms of reserve adequacy from an insurance perspective. Indeed, the fact that India has accumulated an additional \$110 billion of reserves during 2007-8 makes this picture look even more benign than indicated by the ratios in Table 7 . The traditional risks faced by emerging markets with open capital accounts - sudden stops or reversals of capital flows - are therefore not a major concern. Nevertheless, there is clearly an important difference relative to China, which has been accumulating reserves at a hectic pace through current account as well as capital account surpluses.

While China is running a current account surplus in excess of 12 percent of GDP, India registered a current account deficit of 1.5 percent in 2007-08. Is India vulnerable on this dimension? Since foreign exchange reserves amount to about a quarter of GDP, a sudden stop of capital inflows by itself isn't going to create major problems for financing the current account deficit. Moreover, as recent developments have indicated, the RBI is willing to let the rupee depreciate quite significantly to prevent the current account deficit

economies in recent years. Given their current levels of imports and external debt, the levels of reserves in many of these countries are well above those that could be justified on precautionary grounds based on these standard criteria. These authors find that a model that includes the ratio of M2 to GDP does a much better job of fitting cross-country variations in reserve levels.

${ }^{11}$ Indian banks, both private and public, are well capitalized and the ratio of nonperforming loans to total deposits in the banking system is estimated to be less than 2 percent. 
from rising. Nevertheless, current account deficits that reflect consumption booms have often ended disastrously_-is this a risk for India? On this score, there isn't a strong case for concern. Figure 6 shows that both the national savings and investment rates have been rising since the early 2000s, although the investment rate has risen a little faster, accounting for the current account deficit. Thus, India seems to fit the textbook example of a developing country borrowing from abroad to finance investment as its capital to labor ratio is low and its productivity growth is high relative to its major trading partners. ${ }^{12}$

One aspect in common with China is the risk of a banking crisis - a significant tremor in the banking system may trigger a surge of outflow of deposits from the banking system and into foreign currency assets (see Prasad, 2008). Accumulating enough reserves to deal with this potential source of financial instability may seem prudent. But the costs of accumulating such a large stock of reserves - especially in terms of the other distortions in the system needed to maintain a rapid pace of accumulation-implies that this insurance may have costly welfare consequences. On the other hand, a different - and less sanguine - perspective comes from the rapid loss of nearly $\$ 30$ billion worth of reserves in recent weeks as the global financial turmoil led to a flight to quality (and out of emerging markets, including India) and the RBI sought to slow down a sharp depreciation of the rupee. I will return to this issue in the concluding section.

\section{India's Position in the International Financial System}

With its strong growth prospects, India will remain an attractive destination for capital inflows once global financial markets settle down. And its emergence as an economic power will mean that the economy is likely to continue to export private capital. But what forms these inflows and outflows take will of course determine the effects on macroeconomic outcomes. While such prognostications are difficult, a first step is to evaluate how much of various types of flows to emerging markets can be accounted for by

\footnotetext{
${ }^{12}$ Bosworth and Collins (2008) conduct a growth accounting exercise for India and China. They conclude that India has in recent years been experiencing higher productivity growth than most industrial countries (but less than China).
} 
India. For this exercise, we rely on IMF data on total gross inflows into and outflows from all emerging markets and other developing countries. This includes not just flows between these countries and advanced industrial economies but also flows amongst these countries themselves.

Figure 7 shows India's share in total gross flows to emerging markets and other developing countries. This share was just 2 percent in 1997 but shot up to 8 percent in 1998, the second year of the Asian financial crisis, mainly because the overall quantum of flows to emerging markets shrank substantially and economies like China and India that were not devastated by the crisis got more of whatever flows there were. The share has averaged about 5 percent during the 2000s and has been quite stable. India's share of FDI has been quite low over the last decade and inched up to just over 4 percent in 2006. Likewise, India's share of portfolio flows to non-industrial countries hit 12 percent in a couple of years (2001 and 2003) but has otherwise been rather low, amounting to only 4 percent in 2006 (based on the strong portfolio inflows in 2007-08, it has no doubt gone up by at least a couple of percentage points).

In parallel with the inflows it has been receiving, India has of course been investing abroad. Encouraged by the RBI's easing of restrictions on outward FDI, Indian corporates have ramped up these flows, which now account for more than 6 percent of total gross FDI flows emanating from all non-industrial countries (including flows going to other emerging markets). The share of portfolio flows, by contrast, has remained at minuscule levels.

Its low share of total inflows into emerging markets suggests that, despite its growth story, India has a considerable way to go in terms of even obtaining a significant share of total flows to non-industrial countries. It also suggests that, unless there is a fundamental shift in the structures of world financial markets, there could be a lot more capital coming into India if growth prospects remain strong and other international investors "discover" it. ${ }^{13}$

\footnotetext{
${ }^{13}$ Patnaik and Shah (2008) note that India's actual weight in the global equity portfolio is only about one-sixth the predicted weight that India should have according to a standard international capital asset pricing model (ICAPM). This is in fact an improvement relative to 2001, when the
} 
Factors that could lure more capital into India include its relatively high productivity growth, well-developed equity markets, and the profit opportunities from rising income levels and a rapidly expanding domestic market.

At the same time, India's growth is also likely to unleash resources that will result in more capital outflows. As household income levels rise, the demand for international portfolio diversification will increase. Indian institutional investors will also be looking for a wider range of investment opportunities, both domestically and abroad, as their asset pools increase. And Indian companies will almost certainly continue to expand their reach abroad.

The net implication is that there are powerful forces that will impel a substantially higher degree of integration into international financial markets, with capital controls becoming increasingly irrelevant even if they remain on the books. Given India's financial structure and changes in the structure of international financial flows, much of this integration is likely to take the form of inflows and outflows of FDI and portfolio equity, which would of course be a favorable outcome. But the reality is that it will become increasingly difficult to bottle up specific types of flows if the economic incentives favoring them are powerful enough. So the best that macroeconomic policies can do is to foster macroeconomic and financial stability, which could serve to promote the right kinds of flows in both directions.

\section{Implications for Policies Towards Capital Account Liberalization}

India has taken what seems to be a convoluted approach towards capital account convertibility. On the one hand, the capital account has become quite open and restrictions on both inflows and outflows have been eased significantly over time. ${ }^{14}$ Nevertheless, there seems to be a residual element of government control that is maintained on many

actual weight was only about one-tenth the predicted weight (and, of course, India's ICAPM weight has risen substantially--almost four-fold--from 2001 to 2007).

${ }^{14}$ For a chronology, see Bery and Singh (2006). Patnaik and Shah (2008) discuss a few recent steps towards more openness, some remaining restrictions, and their consequences. 
types of flows - sometimes as modest as registration requirements on foreign investors but also some as onerous as virtually keeping foreign investors out of the government debt market — which seems to go against the spirit of unrestricted financial flows. These elements are part of a strategy of cautious and calibrated capital account liberalization that has served India well in at least one dimension — reducing its vulnerability to crises.

In terms of overall de facto financial integration, India has come a long way and has experienced significant volumes of inflows and outflows in recent years. Relative to the size of its economy, however, these flows are rather modest, putting India at the low end of the distribution of de facto financial integration measures in an international comparison across emerging market economies.

The RBI's calibrated approach to capital account opening has resulted in a preponderance of FDI and portfolio liabilities in India's stock of gross external liabilities. All elements of the literature point to this as being a favorable outcome in terms of improving the benefitrisk tradeoff of financial openness. But at the same time the limited degree of openness has probably limited the indirect benefits that seem to accrue from financial integration.

Why not move more rapidly towards fuller capital account convertibility? The recent global financial turmoil suggests that a high degree of caution may be warranted in further opening of the capital account. The question is where to strike the balance - this is a judgment call as the benefits of caution need to be weighed against the possibility that excessive caution in further capital account opening may be holding back financial sector reforms and reducing the independence and effectiveness of monetary policy.

One of the main concerns about capital account liberalization is that it makes exchange rate management harder. Some authors have argued that opening of India's capital account should be resisted as that would make it harder to maintain an undervalued exchange rate and thereby promote export-led growth (e.g., Bhalla, 2007; Subramanian, 2007). This is not a realistic proposition; worse still, it has detracted from many of the potential indirect benefits of financial integration. Although India does not have a formal exchange rate 
target, the Indian rupee has been managed to varying degrees at different times. Even though the nominal exchange rate relative to the U.S. dollar has fluctuated over a wide range in the last decade (Figure 8), the effective exchange rate-measured in either nominal or real terms - has been managed within a much narrower range (Figure 9). The problem is that this has constrained the independence of monetary policy, which now involves a mix between inflation and exchange rate objectives. The RBI does in fact seem to have an implicit medium-term inflation objective (or at least a tolerance level) but also focuses on the exchange rate when needed. As recent events have indicated, this has made the central bank more susceptible to political pressures and might have made it harder for the RBI to manage inflationary pressures. ${ }^{15}$

Resisting exchange rate appreciation has resulted in large costs of sterilizing inflows that are recycled into foreign exchange reserves, which are usually held in low-yield industrial country government bonds. Figure 10, which shows the interest rate differential between Indian and U.S. government securities, drives home this point. The stock of sterilization bonds (Market Stabilization Bonds) also rose sharply during 2006 and 2007 (Figure 11), implying that the quasi-fiscal costs of the RBI's sterilization operations have mounted rapidly. Clearly, tight exchange rate management is not a viable strategy, especially as the capital account is becoming more open in de facto terms over time. This is also evident in developments since the summer of 2008--the RBI has been unable to hold back pressures for the exchange rate to depreciate significantly despite large-scale intervention in the foreign exchange market.

The Rajan Committee report (2008) makes the point that monetary policy would be far more effective if it was focused on the objective of a low and stable inflation rate. Indeed, the evidence suggests that making an inflation objective the key priority of monetary policy would be the best contribution that monetary policy can make to stabilizing domestic business cycles, maintaining financial stability, and even reducing exchange rate

\footnotetext{
${ }^{15}$ Some authors such as Panagariya (2008, see Chapter 10) argue forcefully that the RBI has in fact been very successful with its "pragmatic" approach to monetary and exchange rate policies, delivering a high rate of GDP growth as well as low inflation.
} 
volatility (Rose, 2006). In short, maintaining capital controls as a device to try and manage the exchange rate better is unlikely to work and also weakens monetary policy in insidious ways, especially in terms of managing inflation expectations.

Williamson (2007) argues that India may have liberalized its capital account too quickly and that it should slow down the process noting, in particular, that liberalizing debt flows could be risky and would have few benefits. This proposition has some validity to it but comes up against the reality that it is now very difficult to bottle up specific types of flows. As discussed earlier, the increase in external commercial borrowings in foreign currencies by Indian corporations during 2007 and the first half of 2008 may have been driven in large part by the attempts to resist currency appreciation as well as the absence of other markets to hedge currency risk. Maintaining capital controls simply perpetuates some of these distortions without any actual benefit in terms of reducing inflows. Flows of different forms are ultimately quite fungible and it is increasingly difficult, given the rising sophistication of investors and financial markets, to bottle up specific types of flows. Indeed, rising de facto openness in tandem with de jure controls may lead to the worst combination of outcomes - the complications for domestic macroeconomic management from volatile capital flows and far fewer indirect benefits from financial openness.

One key issue is whether India falls below the threshold conditions that seem to make a big difference to the benefit-risk tradeoff of financial openness. Kose, Prasad and Taylor (2008) report that, while it is difficult to precisely identify the critical levels of the threshold conditions that influence the outcomes of financial openness, there are a few general propositions that do come out of the analysis for particular countries such as India. Given India's level of financial and institutional development, the accumulation of FDI and portfolio equity liabilities is relatively "safe" as the levels of these two thresholds for such liabilities are rather low. As for debt accumulation, India is moving towards the threshold in terms of financial development but is not there yet.

Another important threshold condition is related to trade integration. Many authors have found that greater openness to trade not only reduces the risks of financial crises but also 
makes it easier for a country to recover quickly if it does get hit by a crisis (see, e.g., Frankel and Cavallo, 2004, and references therein). On this dimension, it is encouraging that there has been a rapid increase in India's external trade, with the standard trade openness measure (ratio of the sum of exports and imports to GDP) nearly doubling from its level of 25 percent in 2000 (see Figure 12).

Thus, in terms of the collateral benefits-thresholds framework, India is a good example of a country where the benefit-risk tradeoff of further capital account is finely balanced. It turns out that there is another important threshold condition, which is the level of financial integration itself. Countries that are more integrated into international financial markets seem to achieve better risk sharing outcomes and also seem to suffer few ill effects of even a stock of external liabilities that is tilted towards more debt.

Given the cushion provided by India's high level of reserves, there is now an opportunity to push forward more aggressively with certain aspects of capital account liberalization in order to gain more of the indirect benefits of financial integration. For instance, a specific recommendation of the Rajan Committee (2008) is that allowing foreign investors to invest in government bonds could improve the liquidity and depth of this market. This would have numerous ancillary benefits. A deep and well-functioning government bond market is a prerequisite for serving as a benchmark for pricing corporate bonds, which could allow that market to develop. By providing an additional source of debt financing, it would create some room for the government to reduce the financing burden it currently imposes on banks through the statutory liquidity ratio - the requirement that banks hold a certain portion of their deposits in government bonds. And it might even have the beneficial effect of imposing some discipline on fiscal policy since foreign investors could pull out and raise the cost of debt financing if the government budget deficit were to start rising again.

An opportunistic approach to liberalization of outflows during a period of surging inflows is also worth considering as it would serve multiple objectives. If undertaken in a controlled manner along the lines suggested by Prasad and Rajan (2008), it would generate a variety of collateral benefits - sterilization of inflows, securities market development, 
international portfolio diversification for households - without the risks of a full and irrevocable opening of the taps for outflows. More recently, the RBI has taken an opportunistic approach to liberalizing inflows by raising ceilings on external commercial borrowings in order to compensate for capital outflows. These are steps in the right direction. One potential problem is that such measures--when taken in isolation and perceived as subject to reversal if they are not seen as part of a broader and well-articulated capital account liberalization agenda--are not likely to be very productive.

Does all this mean that financial integration should be a key policy priority and that the capital account should be opened at one fell swoop? Hardly. As Panagariya notes (2008), liberalizing all types of short-term flows in a precipitous manner could heighten the risk of financial crisis, which in turn would put paid to a whole host of other essential reforms. But my perspective on this is slightly different - that holding exchange rate policy and financial reforms hostage to the notion that the capital account can be kept closed or restricted for a prolonged period (even 3-5 years) may ultimately prove to be a costly proposition. While full capital account convertibility may not be an immediate priority, it is important not to lose sight of the longer-term objective while dealing with short-term pressures caused by surges of inflows or outflows. Indeed, in terms of facilitating adjustment and deriving more indirect benefits, there is a case to be made for taking advantage of the various favorable circumstances discussed in this paper and laying down a well-articulated roadmap towards rapid capital account liberalization in the near term (next 2-3 years) rather than over the indefinite future. ${ }^{16}$

\footnotetext{
${ }^{16}$ The reports of the Mistry Committee (2007) and Rajan Committee (2008) lay out a fairly aggressive timetable, noting the large benefits that could be gained from financial openness, including how it could foster more effective monetary policy and boost financial sector reforms. The Tarapore Committee (2006) recommends a much slower pace of liberalization. Rajan and Zingales (2003) note that capital account liberalization can also be useful as a framework for building consensus around reforms and for thwarting coalitions that try to block reforms.
} 


\section{References}

Aizenman, Joshua, Brian Pinto and Arthur Radziwill. 2007. "Sources for Financing Domestic Capital--Is Foreign Saving a Viable Option for Developing Countries?" Journal of International Money and Finance, 26(5): 682-702.

Aoki, Kosuke, Gianluca Benigno and Nobuhiro Kiyotaki. 2005. "Adjusting to Capital Account Liberalization." Working Paper, London School of Economics.

Arteta, Carlos, Barry Eichengreen, and Charles Wyplosz. 2003. "When Does Capital Account Liberalization Help More than It Hurts?" in Economic Policy in the International Economy: Essays in Honor of Assaf Razin, edited by Elhanan Helpman and Efraim Sadka. Cambridge University Press.

Bekaert, Geert, Campbell R. Harvey, and Christian Lundblad. 2005. “Does Financial Liberalization Spur Growth?” Journal of Financial Economics, 77(1): 3-55.

Bery, Suman, and Kanhaiya Singh. 2006. "Domestic Financial Liberalization and International Financial Integration: An Indian Perspective.” In China and India: Learning from Each Other, edited by Jahangir Aziz, Eswar Prasad, and Steven Dunaway. International Monetary Fund: 145-180.

Bhagwati, Jagdish. 1998. "The Capital Myth: The Difference Between Trade in Widgets and Trade in Dollars." Foreign Affairs, 77:7-12

Bhalla, Surjit S. 2007. "Second Among Equals: The Middle Class Kingdoms of India and China." Peterson Institute of International Economics.

Bosworth, Barry and Susan M. Collins. Winter 2008. "Accounting for Growth: Comparing China and India.” Journal of Economic Perspectives, 22(1):45-66.

Chinn, Menzie, and Hiro Ito. 2006. "What Matters for Financial Development? Capital Controls, Institutions and Interactions." Journal of Development Economics, 81(1): 163-192.

Claessens, Stijn, Aslí Demirgüç-Kunt, and Harry Huizinga. 2001. "How Does Foreign Entry Affect Domestic Banking Markets?” Journal of Banking and Finance, 25(5): 891-911.

Claessens, Stijn, and Luc Laeven. 2004. "What Drives Bank Competition? Some International Evidence.” Journal of Money, Credit, and Banking, 36(3): 563-83.

Clarke, George R. G., Robert Cull, Maria Soledad Martinez Peria, and Susana M. Sanchez. 2003. "Foreign Bank Entry: Experience, Implications for Developing Economies, and Agenda for Further Research." World Bank Research Observer, 8(1): 25-59. 
Desai, Padma. 2003. Financial Crisis, Contagion, and Containment: From Asia to Argentina. Princeton University Press.

Edwards, Sebastian. 2007. "Capital Controls, Sudden Stops and Current Account Reversals." in International Capital Flows, edited by Sebastian Edwards. University of Chicago Press.

Eichengreen, Barry. 2007."The Cautious Case for Capital Flows." Presented to Rating Agency Malaysia's conference on "Free Capital Mobility: What's in Store for Asia?" held in Singapore, August 1.

Forbes, Kristin J. 2007. "The Microeconomic Evidence on Capital Controls: No Free Lunch." in International Capital Flows, edited by Sebastian Edwards. University of Chicago Press.

Frankel, Jeffrey, and Eduardo A. Cavallo. 2004. "Does Openness to Trade Make Countries More Vulnerable to Sudden Stops or Less? Using Gravity to Establish Causality." NBER Working Paper 10957.

Goldberg, Linda. 2004. "Financial-Sector Foreign Direct Investment and Host Countries: New and Old Lessons.” NBER Working Paper 10441.

Gourinchas, Pierre-Olivier, and Olivier Jeanne. 2007. "Capital Flows to Developing Countries: The Allocation Puzzle.” NBER Working Paper No. 13602.

Henry, Peter B. 2000. "Stock Market Liberalization, Economic Reform, and Emerging Market Equity Prices.” Journal of Finance, 55(2): 529-64.

Jeanne, Olivier. 2007. "International Reserves in Emerging Market Countries: Too Much of a Good Thing?” Brookings Papers on Economic Activity, 2001(1): 1-80.

Kaminsky, Graciela, Carmen M. Reinhart, and Carlos A. Vegh. 2004. "When it Rains, it Pours: Procyclical Capital Flows and Macroeconomic Policies.” NBER Macroeconomics Annual 2004.

Klein, Michael, and Giovanni Olivei. 2008. "Capital Account Liberalization, Financial Depth, and Economic Growth.” Journal of International Money and Finance, 27(6): 861-875.

Kletzer, Kenneth M. 2004. "Liberalizing Capital Flows in India: Financial Repression, Macroeconomic Policy, and Gradual Reforms.” India Policy Forum 2004, edited by Suman Bery, Barry Bosworth, Arvind Panagariya. Brookings Institution Press and NCAER: 227-263. 
Kose, M. Ayhan, Eswar Prasad, Kenneth Rogoff and Shang-Jin Wei. 2006. "Financial Globalization: A Reappraisal.” NBER Working Paper No. 12484. Forthcoming in IMF Staff Papers.

Kose, M. Ayhan, Eswar Prasad, Kenneth Rogoff, and Shang-Jin Wei. 2008. "Financial Globalization and Economic Policies." Forthcoming in Handbook of Development Economics. edited by Dani Rodrik and Mark Rosenzweig.

Kose, M. Ayhan, Eswar Prasad, and Marco Terrones. 2007. "How Does Financial Globalization Affect Risk Sharing? Patterns and Channels." Forthcoming in Journal of Development Economics.

Kose, M. Ayhan, Eswar Prasad, and Ashley Taylor. 2008. "Thresholds in the Process of Financial Integration." Manuscript, IMF and Cornell University.

Kose, M. Ayhan, Eswar Prasad, and Marco Terrones. 2008. "Does Openness to International Financial Flows Contribute to Productivity Growth." Manuscript, IMF and Cornell University.

Krueger, Anne O., and Jungho Yoo. 2002. "Chaebol Capitalism and the CurrencyFinancial Crisis in Korea." in Preventing Currency Crises in Emerging Markets, edited by Sebastian Edwards and Jeffrey Frankel. University of Chicago Press: 461-501.

Lane, Philip R., and Gian Maria Milesi-Ferretti. 2007. "The External Wealth of Nations Mark II: Revised and Extended Estimates of Foreign Assets and Liabilities, 19702004." Journal of International Economics, 73(2):223-250.

Lane, Philip R., and Sergio L. Schmukler. 2007. "The International Financial Integration of China and India." in Dancing with Giants: China, India and the World Economy, The World Bank.

Levine, Ross, and Sara Zervos. 1998. "Capital Control Liberalization and Stock Market Development.” World Development, 26(7): 1169-83.

Mishkin, Frederick. 2006. The Next Great Globalization: How Disadvantaged Nations Can Harness Their Financial Systems to Get Rich. Princeton University Press.

Mohan, Rakesh. 2007. "Recent Financial Market Developments and Implications For Monetary Policy.” Valedictory Address at IIF's Inaugural Asia Regional Economic Forum on September 20.

Mohan, Rakesh. 2008. "Capital Flows to India.” Manuscript, Reserve Bank of India. Paper presented at annual meeting of Deputy Governors at BIS, February. 
Mukerji, Purba, 2009, "Ready for Capital Account Convertibility." Forthcoming in Journal of International Money and Finance.

Obstfeld, Maurice, Jay C. Shambaugh, and Alan M. Taylor. 2008. "Financial Stability, the Trilemma, and International Reserves.” CEPR Discussion Papers No. 6693.

Panagariya, Arvind. 2008. India: The Emerging Giant. Oxford University Press.

Patnaik, Ila. 2004. "India's Experience with a Pegged Exchange Rate." India Policy Forum 2004, edited by Suman Bery, Barry Bosworth, Arvind Panagariya. Brookings Institution Press and NCAER: 189-216.

Patnaik, Ila, and Ajay Shah. 2008. "Managing Capital Flows: The Case of India." NIPFP Working Paper 2008-52.

Prasad, Eswar. 2008. “Is China's Growth Miracle Built to Last?” IZA Discussion Paper No. 2995. Forthcoming in China Economic Review.

Prasad, Eswar, Raghuram Rajan, and Arvind Subramanian. 2007. "Foreign Capital and Economic Growth." Brookings Papers on Economic Activity, 2007(1): 153-230.

Prasad, Eswar, and Raghuram Rajan. 2008. "A Pragmatic Approach to Capital Account Liberalization.” Journal of Economic Perspectives, 22(3):149-172.

Prasad, Eswar, and Shang-Jin Wei. 2007. "The Chinese Approach to Capital Inflows: Patterns and Possible Explanations." in Capital Controls and Capital Flows in Emerging Economies: Policies, Practices, and Consequences, edited by Sebastian Edwards. University of Chicago Press.

Rajan, Raghuram, and Luigi Zingales. 2003. "The Great Reversals: The Politics of Financial Development in the $20^{\text {th }}$ Century." Journal of Financial Economics, 69: $5-50$.

Reddy, Yaga V. 2005. "Overcoming Challenges in a Globalising Economy: Managing India's External Sector," Lecture delivered at the Foreign Policy Center, London, on June 23. (www.rbi.org.in [June 2005]).

Reddy, Yaga V. 2007. “Converting a Tiger.” Finance \& Development, 44(1): 20-23.

Report of the Committee on Fuller Capital Account Convertibility (S. S. Tarapore). 2006. (www.rbi.org.in/scripts/PublicationReportDetails.aspx?UrlPage=\&ID=468)

Report of the Committee on Fuller Capital Account Convertibility (Chairman: S.S. Tarapore). 1997.

(www.rbi.org.in/scripts/PublicationReportDetails.aspx?UrlPage=\&ID=169) 
Report of the High Level Committee on Financial Sector Reforms (Chairman: Raghuram Rajan). 2008. (http://planningcommission.nic.in/reports/genrep/report fr.htm)

Report on Making Mumbai an International Financial Center (Chairman: Percy Mistry). 2007. (http://finmin.nic.in/reports/index.html)

Rodrik, Dani. 1998. “Who Needs Capital-Account Convertibility?” Essays in International Finance 207. Princeton, New Jersey: Princeton University.

Rodrik, Dani, 2007. "The Real Exchange Rate and Economic Growth: Theory and Evidence.” Manuscript, Kennedy School of Government, Harvard University.

Rodrik, Dani, and Arvind Subramanian. 2008. "Why Did Financial Globalization Disappoint?" Manuscript, Harvard University. Forthcoming in IMF Staff Papers.

Rose, Andrew. 2007. "A Stable International System Emerges: Bretton Woods, Reversed." Journal of International Money and Finance, 26(5):663-681.

Shah, Ajay. 2008. "New Issues in Indian Macro Policy." Forthcoming in Business Standard India, 2008 edited by T.N. Ninan. (Business Standard Books).

Williamson, John. 2006. "Why Capital Account Convertibility in India Is Premature." Economic and Political Weekly May 13:1848-1850. 
Table 1. De Jure Capital Account Openness

\begin{tabular}{|c|c|c|c|c|c|c|}
\hline & \multirow{2}{*}{$\begin{array}{c}\text { Full Sample } \\
\text { Median }\end{array}$} & \multicolumn{3}{|c|}{ Emerging Markets } & \multirow[t]{2}{*}{ India } & \multirow[t]{2}{*}{ China } \\
\hline & & Minimum & Median & Maximum & & \\
\hline \multicolumn{7}{|c|}{ Chinn Ito } \\
\hline 1985 & -1.13 & -1.80 & -1.13 & 2.54 & -1.13 & -1.13 \\
\hline 1995 & -0.09 & -1.80 & -0.09 & 2.54 & -1.13 & -1.13 \\
\hline 2006 & 0.14 & -1.13 & 0.03 & 2.54 & -1.13 & -1.13 \\
\hline \multicolumn{7}{|l|}{ Edwards } \\
\hline 1985 & 50.00 & 12.50 & 37.50 & 75.00 & 25.00 & 37.50 \\
\hline 1995 & 75.00 & 25.00 & 50.00 & 100.00 & 25.00 & 37.50 \\
\hline 2000 & 81.25 & 37.50 & 62.50 & 100.00 & 75.00 & 37.50 \\
\hline \multicolumn{7}{|l|}{ Miniane } \\
\hline 1985 & 0.86 & 0.83 & 0.86 & 1.00 & 0.83 & \\
\hline 1995 & 0.43 & 0.71 & 0.86 & 1.00 & 0.83 & \\
\hline 2000 & 0.36 & 0.71 & 0.86 & 0.86 & 0.86 & \\
\hline
\end{tabular}

Note: The Chinn-Ito index goes from -2.54 to 2.54 , with a higher number indicating a more open capital account. The Edwards index goes from 0 to 100, with a higher number indicating a more open capital account. The Miniane index goes from 0 to 1 , with a lower number indicating a more open capital account.

Source: Edwards (2007), Chinn and Ito (2006), Miniane (2004) and author's calculations. 
Table 2. The Balance of Payments

(in billions of U.S. dollars)

\begin{tabular}{|c|c|c|c|c|c|c|c|c|c|c|c|c|}
\hline & $1997-98$ & 1998-99 & 1999-00 & $2000-01$ & 2001-02 & $2002-03$ & 2003-04 & 2004-05 & $2005-06$ & $2006-07$ & $2007-08$ & 2008-09* \\
\hline Gross international reserves & 29.7 & 33.2 & 38.7 & 42.9 & 54.7 & 76.1 & 113.0 & 141.5 & 151.6 & 199.2 & 309.7 & 312.1 \\
\hline (in percent of GDP) & 7.2 & 8.0 & 8.6 & 9.3 & 11.4 & 15.0 & 18.8 & 20.3 & 18.8 & 21.6 & 27.2 & \\
\hline Change in international reserves & 2.9 & 3.5 & 5.5 & 4.2 & 11.8 & 21.4 & 36.9 & 28.5 & 10.1 & 47.6 & 110.5 & 2.4 \\
\hline $\begin{array}{l}\text { A. Current account balance } \\
\text { (in percent of GDP) }\end{array}$ & $\begin{array}{l}-5.5 \\
-1.3\end{array}$ & $\begin{array}{l}-4.0 \\
-1.0\end{array}$ & $\begin{array}{l}-4.7 \\
-1.0\end{array}$ & $\begin{array}{l}-2.7 \\
-0.6\end{array}$ & $\begin{array}{l}3.4 \\
0.7\end{array}$ & $\begin{array}{l}6.3 \\
1.2\end{array}$ & $\begin{array}{r}14.1 \\
2.3\end{array}$ & $\begin{array}{l}-2.5 \\
-0.4\end{array}$ & $\begin{array}{l}-9.9 \\
-1.2\end{array}$ & $\begin{array}{l}-9.8 \\
-1.1\end{array}$ & $\begin{array}{c}-17.4 \\
-1.5\end{array}$ & -10.7 \\
\hline $\begin{array}{l}\text { Merchandise trade balance } \\
\text { (in percent of GDP) }\end{array}$ & $\begin{array}{r}-15.5 \\
-3.8\end{array}$ & $\begin{array}{r}-13.2 \\
-3.2\end{array}$ & $\begin{array}{c}-17.8 \\
-4.0\end{array}$ & $\begin{array}{r}-12.5 \\
-2.7\end{array}$ & $\begin{array}{c}-11.6 \\
-2.4\end{array}$ & $\begin{array}{l}-10.7 \\
-2.1\end{array}$ & $\begin{array}{l}-13.7 \\
-2.3\end{array}$ & $\begin{array}{l}-33.7 \\
-4.8\end{array}$ & $\begin{array}{r}-51.9 \\
-6.4\end{array}$ & $\begin{array}{r}-63.2 \\
-6.8\end{array}$ & $\begin{array}{r}-90.1 \\
-7.9\end{array}$ & -31.6 \\
\hline $\begin{array}{l}\text { B. Capital account balance } \\
\text { FDI, net } \\
\text { portfolio flows, net }\end{array}$ & $\begin{array}{l}9.8 \\
3.5 \\
1.8\end{array}$ & $\begin{array}{r}8.4 \\
2.4 \\
-0.1\end{array}$ & $\begin{array}{r}10.4 \\
2.1 \\
3.0\end{array}$ & $\begin{array}{l}8.8 \\
3.3 \\
2.6\end{array}$ & $\begin{array}{l}8.6 \\
4.7 \\
2.0\end{array}$ & $\begin{array}{r}10.8 \\
3.2 \\
0.9\end{array}$ & $\begin{array}{r}16.7 \\
2.4 \\
11.4\end{array}$ & $\begin{array}{r}28.0 \\
3.7 \\
9.3\end{array}$ & $\begin{array}{r}25.5 \\
3.0 \\
12.5\end{array}$ & $\begin{array}{r}45.8 \\
8.5 \\
7.1\end{array}$ & $\begin{array}{r}108.0 \\
15.5 \\
29.3\end{array}$ & $\begin{array}{l}13.2 \\
10.1 \\
-4.2\end{array}$ \\
\hline C. Errors and omissions, net & 0.2 & -0.2 & 0.7 & -0.3 & -0.2 & -0.2 & 0.6 & 0.6 & -0.5 & 0.6 & 1.5 & -0.3 \\
\hline D. Valuation change & -1.6 & -0.7 & -0.9 & -1.7 & 0.0 & 4.5 & 5.5 & 2.4 & -5.0 & 11.0 & 18.4 & 0.2 \\
\hline \multicolumn{13}{|l|}{ Memorandum Items: } \\
\hline $\begin{array}{l}\text { Non-FDI capital account balance } \\
\text { (including errors and omissions) }\end{array}$ & 6.5 & 5.9 & 9.0 & 5.3 & 3.6 & 7.4 & 14.9 & 24.9 & 22.0 & 37.9 & 94.0 & 2.8 \\
\hline Nominal GDP & 410.0 & 414.0 & 450.0 & 460.0 & 478.0 & 508.0 & 602.0 & 696.0 & 806.0 & 922.7 & 1140.0 & \\
\hline
\end{tabular}

Sources: CEIC, RBI and author's calculations.

Notes: The data for 2008-09 are end June data.The non-FDI capital account balance is the capital account balance minus net FDI plus net errors and omissions. 
Table 3. A Decomposition of the Recent Reserve Buildup (in billions of U.S. dollars)

\begin{tabular}{|c|c|c|c|c|c|}
\hline & \multicolumn{3}{|c|}{ Annual averages } & \multicolumn{2}{|c|}{ Changes } \\
\hline & 1998-2001 & $2001-06$ & $2006-08$ & $\begin{array}{r}2001-06 \\
-1998-2001\end{array}$ & $\begin{array}{r}2006-08 \\
-2001-06\end{array}$ \\
\hline & (1) & (2) & (3) & (2) - (1) & (3) - (2) \\
\hline Increase in foreign reserves & 4.4 & 21.7 & 79.1 & 17.3 & 57.3 \\
\hline Current account balance & -3.8 & 2.3 & -13.6 & 6.1 & -15.9 \\
\hline Capital account balance & 9.2 & 17.9 & 76.9 & 8.7 & 59.0 \\
\hline FDI, net & 2.6 & 3.4 & 12.0 & 0.8 & 8.6 \\
\hline Errors and omissions, net & 0.1 & 0.1 & 1.1 & 0.0 & 1.0 \\
\hline Valuation Changes & -1.1 & 1.5 & 14.7 & 2.6 & 13.2 \\
\hline $\begin{array}{l}\text { Non-FDI capital account balance } \\
\text { (including errors and omissions) }\end{array}$ & 6.7 & 14.6 & 66.0 & 7.8 & 51.4 \\
\hline
\end{tabular}

Sources: CEIC, RBI and author's calculations.

Notes: The non-FDI capital account balance is the capital account balance minus net FDI plus net errors and omissions. 


\section{Table 4. Composition of Gross Inflows and Gross Outflows}

\begin{tabular}{|c|c|c|c|c|c|c|}
\hline \multicolumn{7}{|c|}{ Inflows } \\
\hline & \multicolumn{2}{|c|}{ Gross Inflows } & \multicolumn{4}{|c|}{ Components } \\
\hline & \multirow[b]{2}{*}{ (USD billions) } & \multirow[b]{2}{*}{ (percent of GDP) } & FDI & rtfolio & Loans & Other \\
\hline & & & \multicolumn{4}{|c|}{ (as percent of gross inflows) } \\
\hline $1995-96$ & 7.8 & 2.1 & 27.6 & 34.3 & 28.4 & 9.6 \\
\hline $1996-97$ & 13.6 & 3.5 & 20.9 & 24.4 & 35.3 & 19.4 \\
\hline $1997-98$ & 14.0 & 3.3 & 25.4 & 13.1 & 34.3 & 27.2 \\
\hline 1998-99 & 10.8 & 2.5 & 23.0 & -0.6 & 41.0 & 36.7 \\
\hline 1999-00 & 10.8 & 2.4 & 20.0 & 28.0 & 14.8 & 37.2 \\
\hline $2000-01$ & 14.9 & 3.2 & 27.0 & 18.5 & 35.3 & 19.2 \\
\hline 2001-02 & 9.2 & 1.9 & 66.7 & 22.0 & -13.7 & 25.0 \\
\hline $2002-03$ & 4.0 & 0.8 & 125.7 & 24.4 & -96.1 & 46.0 \\
\hline 2003-04 & 16.3 & 2.8 & 26.4 & 69.5 & -26.7 & 30.8 \\
\hline 2004-05 & 35.4 & 5.1 & 16.9 & 26.3 & 30.9 & 25.9 \\
\hline $2005-06$ & 35.2 & 4.3 & 25.3 & 35.4 & 22.4 & 16.9 \\
\hline 2006-07 & 61.3 & 6.7 & 35.9 & 11.4 & 40.1 & 12.6 \\
\hline 2007-08 & 98.1 & 8.6 & 18.3 & 33.5 & 28.9 & 19.3 \\
\hline
\end{tabular}

\section{Outflows}

\begin{tabular}{|c|c|c|c|c|c|c|}
\hline & \multicolumn{2}{|c|}{ Gross Outflows } & \multicolumn{4}{|c|}{ Components } \\
\hline & (USD billions) & (percent of GDP) & \multicolumn{4}{|c|}{ (as percent of gross outflows) } \\
\hline $1995-96$ & 3.5 & 0.9 & 5.4 & & 0.2 & 94.4 \\
\hline $1996-97$ & 3.1 & 0.8 & 6.1 & & 0.0 & 93.9 \\
\hline $1997-98$ & 2.5 & 0.6 & 1.5 & & 0.4 & 98.0 \\
\hline 1998-99 & 2.9 & 0.7 & 3.4 & & 0.5 & 96.0 \\
\hline 1999-00 & 2.9 & 0.6 & 2.5 & & -0.3 & 97.8 \\
\hline $2000-01$ & 3.5 & 0.8 & 21.6 & 4.8 & 0.6 & 72.9 \\
\hline 2001-02 & 3.1 & 0.6 & 45.4 & 2.3 & 2.7 & 49.6 \\
\hline 2002-03 & 3.1 & 0.6 & 57.9 & 1.1 & 0.7 & 40.2 \\
\hline 2003-04 & 4.3 & 0.7 & 44.9 & 0.0 & 2.3 & 52.7 \\
\hline 2004-05 & 6.8 & 1.0 & 33.5 & 0.4 & 4.9 & 61.2 \\
\hline $2005-06$ & 10.9 & 1.3 & 53.9 & 0.0 & 2.9 & 43.2 \\
\hline 2006-07 & 17.5 & 1.9 & 77.0 & -0.3 & 1.8 & 21.5 \\
\hline $2007-08$ & 26.0 & 2.3 & 64.6 & -0.6 & 0.1 & 35.9 \\
\hline
\end{tabular}

Note: Prior to 2000-01, outward FDI and portfolio outflows were not reported separately.

Source: CEIC, RBI and author's calculations. 
Table 5. External Debt Stocks: Levels and Composition

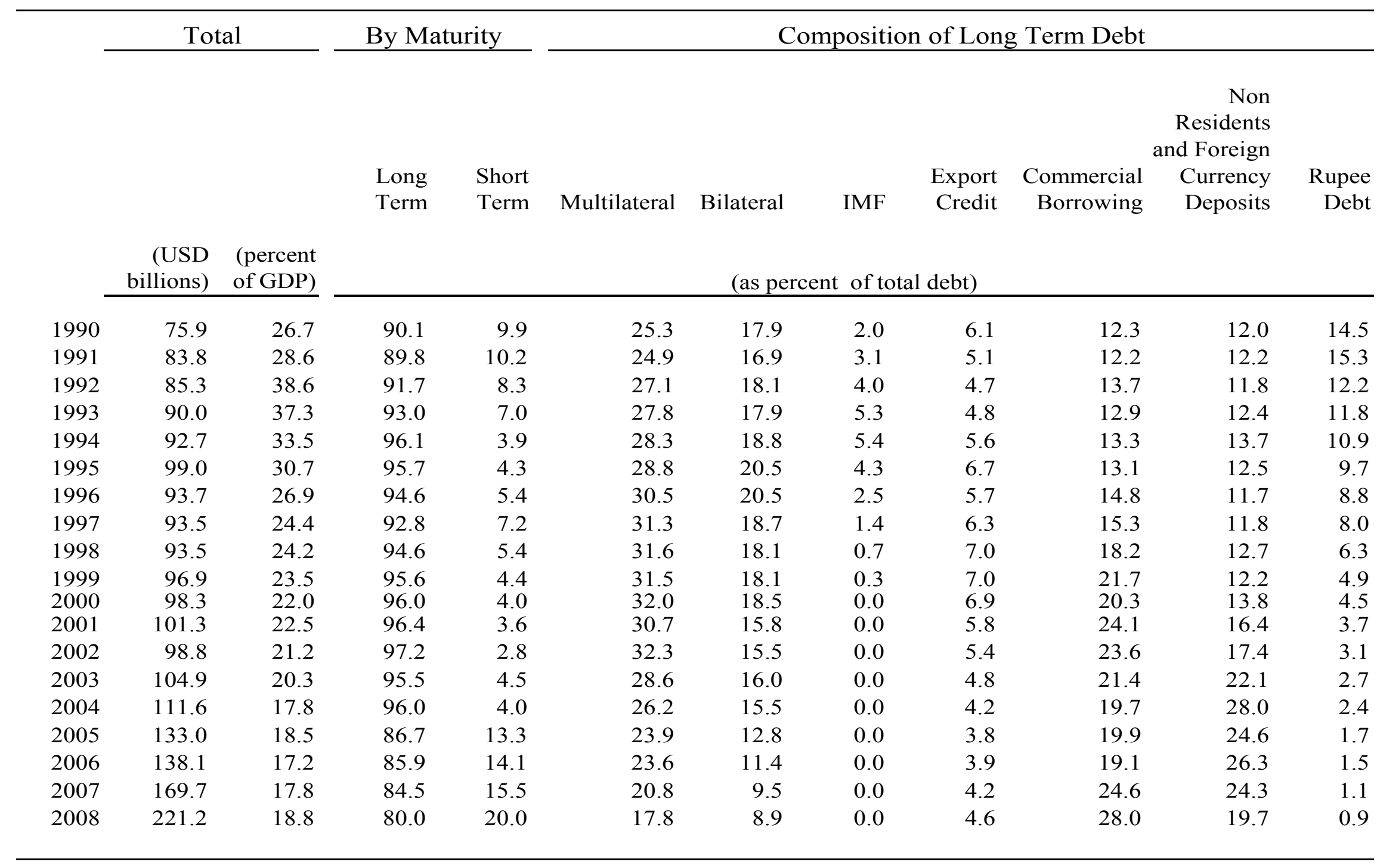

Note: 2005 onwards, Short term debt is the difference between the total and long term debt.

Source: CEIC, Ministry of Finance, Govt. of India and author's calculations. 
Table 6. India's International Investment Position (in billions of U.S. dollars)

\begin{tabular}{|c|c|c|c|c|c|c|c|c|c|c|c|c|}
\hline & $1996-97$ & $1997-98$ & 1998-99 & 1999-00 & 2000-01 & 2001-02 & $2002-03$ & 2003-04 & 2004-05 & 2005-06 & 2006-07 & 2007-08 \\
\hline Net Position & -81 & -81 & -79 & -77 & -76 & -69 & -60 & -47 & -54 & -60 & -62 & -53 \\
\hline A. Assets & 38 & 42 & 47 & 55 & 62 & 74 & 96 & 136 & 166 & 184 & 246 & 381 \\
\hline 1. FDI & 1 & 1 & 2 & 2 & 3 & 4 & 6 & 8 & 10 & 16 & 29 & 46 \\
\hline 2. Portfolio & $\mathbf{0}$ & $\mathbf{0}$ & $\mathbf{0}$ & $\mathbf{0}$ & 1 & 1 & 1 & $\mathbf{0}$ & $\mathbf{0}$ & 1 & 1 & 1 \\
\hline Equity & 0 & 0 & 0 & 0 & 0 & 0 & 0 & 0 & 0 & 1 & 1 & 1 \\
\hline Debt & 0 & 0 & 0 & 0 & 0 & 0 & 0 & 0 & 0 & 0 & 0 & 0 \\
\hline 3. Other investment & 10 & 11 & 12 & 14 & 16 & 14 & 13 & 15 & 14 & 15 & 16 & 25 \\
\hline 4. Reserve assets & 27 & 30 & 33 & 39 & 43 & 55 & 76 & 113 & 142 & 152 & 199 & 310 \\
\hline Foreign exchange reserves & 22 & 26 & 30 & 35 & 40 & 51 & 72 & 107 & 136 & 145 & 192 & 299 \\
\hline B. Liabilities & 119 & 122 & 126 & 132 & 139 & 143 & 156 & 183 & 220 & 244 & 308 & 434 \\
\hline 1. FDI & 11 & 14 & 15 & 18 & 20 & 25 & 31 & 38 & 44 & 52 & 76 & 116 \\
\hline 2. Portfolio & 19 & 20 & 23 & 25 & 31 & 32 & 32 & 44 & 56 & 64 & 79 & 119 \\
\hline Equity & 14 & 14 & 13 & 16 & 17 & 19 & 20 & 34 & 43 & 55 & 63 & 98 \\
\hline Debt & 5 & 6 & 10 & 9 & 14 & 13 & 12 & 10 & 13 & 10 & 16 & 21 \\
\hline 3. Other investment & 89 & 88 & 87 & 89 & 87 & 86 & 92 & 101 & 119 & 128 & 152 & 199 \\
\hline
\end{tabular}

Source: Reserve Bank of India and CEIC. 
Table 7. Reserve Adequacy

(ratio of reserves to relevant variables)

\begin{tabular}{rrrrr}
\hline & $\begin{array}{r}\text { Non-FDI } \\
\text { external } \\
\text { liabilities }\end{array}$ & $\begin{array}{r}\text { External } \\
\text { Debt }\end{array}$ & $\begin{array}{r}\text { Months of } \\
\text { imports }\end{array}$ & M3 \\
& & & & \\
\hline 1992 & & 0.1 & 3.3 & 0.1 \\
1993 & & 0.2 & 6.6 & 0.1 \\
1994 & & 0.2 & 7.6 & 0.1 \\
1995 & & 0.2 & 4.8 & 0.1 \\
1996 & 0.2 & 0.2 & 6.0 & 0.1 \\
1997 & 0.2 & 0.3 & 6.7 & 0.1 \\
1998 & 0.3 & 0.3 & 6.7 & 0.1 \\
1999 & 0.3 & 0.4 & 6.9 & 0.1 \\
2000 & 0.3 & 0.4 & 7.4 & 0.1 \\
2001 & 0.4 & 0.5 & 9.6 & 0.2 \\
2002 & 0.6 & 0.7 & 10.8 & 0.2 \\
2003 & 0.7 & 0.9 & 12.6 & 0.2 \\
2004 & 0.8 & 1.0 & 11.4 & 0.3 \\
2005 & 0.8 & 1.1 & 9.5 & 0.2 \\
2006 & 0.9 & 1.1 & 9.6 & 0.3 \\
2007 & 0.9 & 1.4 & 12.5 & 0.3 \\
\hline
\end{tabular}

Source: CEIC, RBI and author's calculations. 
Figure 1. De Facto Financial Openness

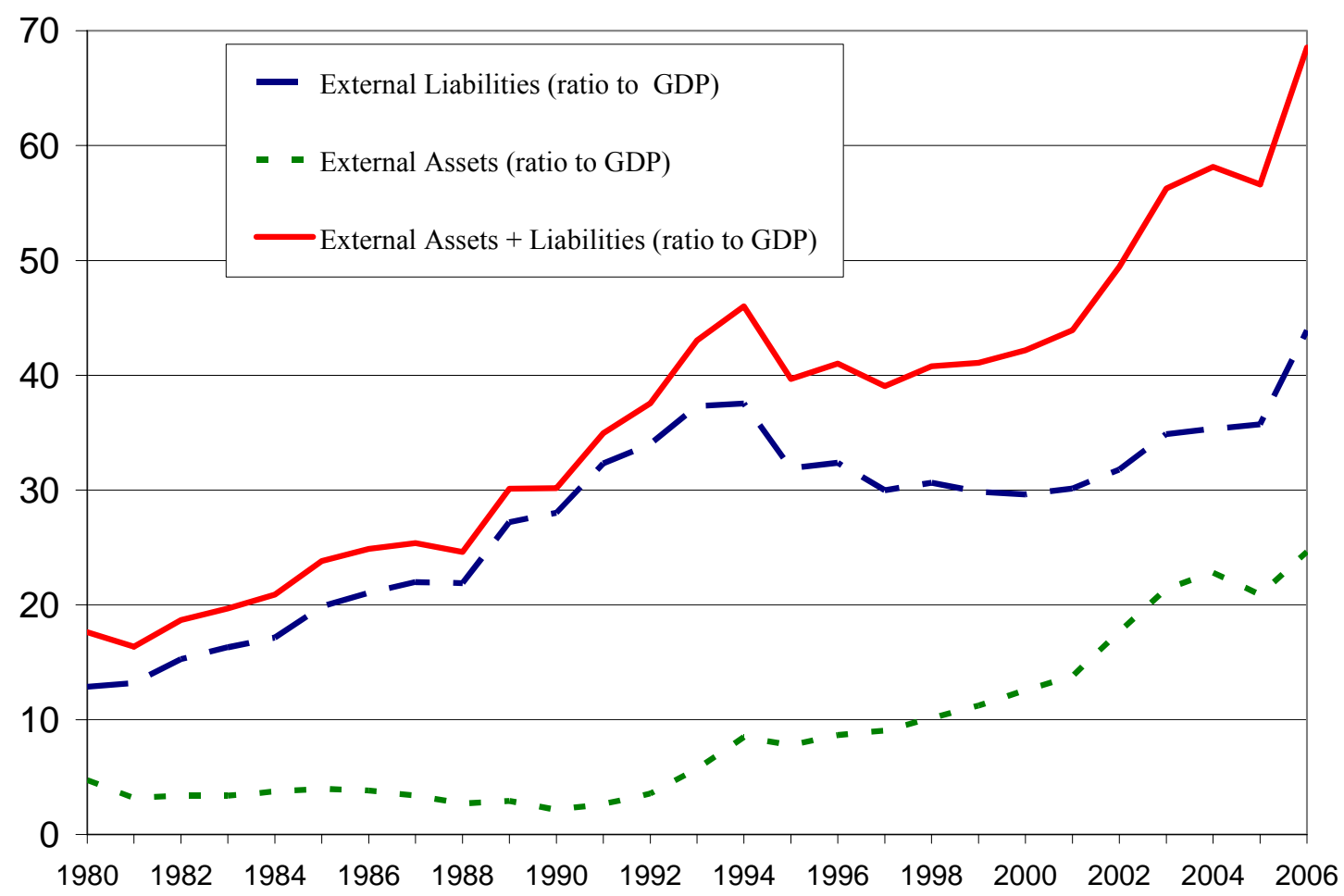

Source: Lane and Milesi-Ferretti (2006) dataset and author's calculations. 
Figure 2. De Facto Financial Openness: Emerging Markets

1995

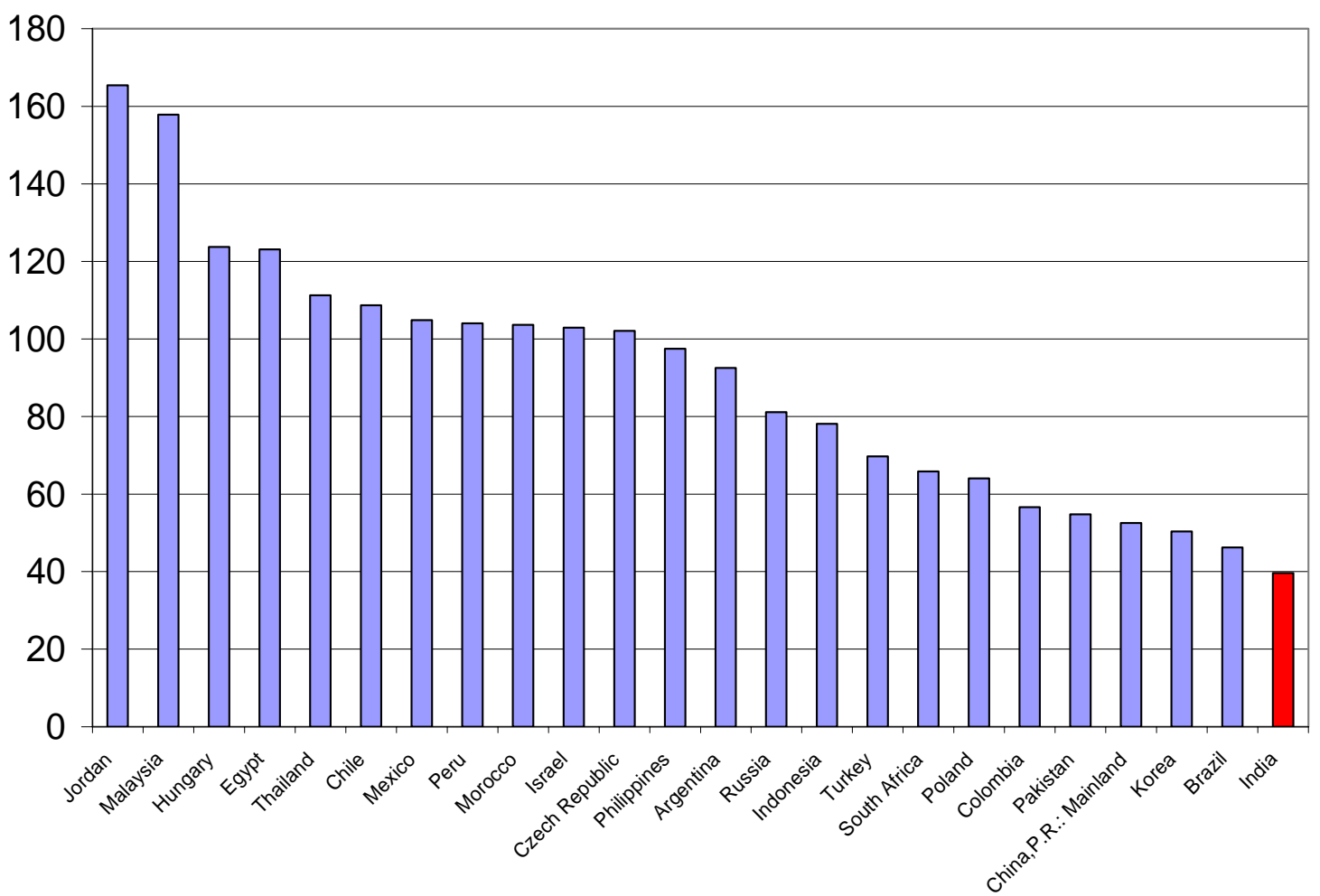

2006

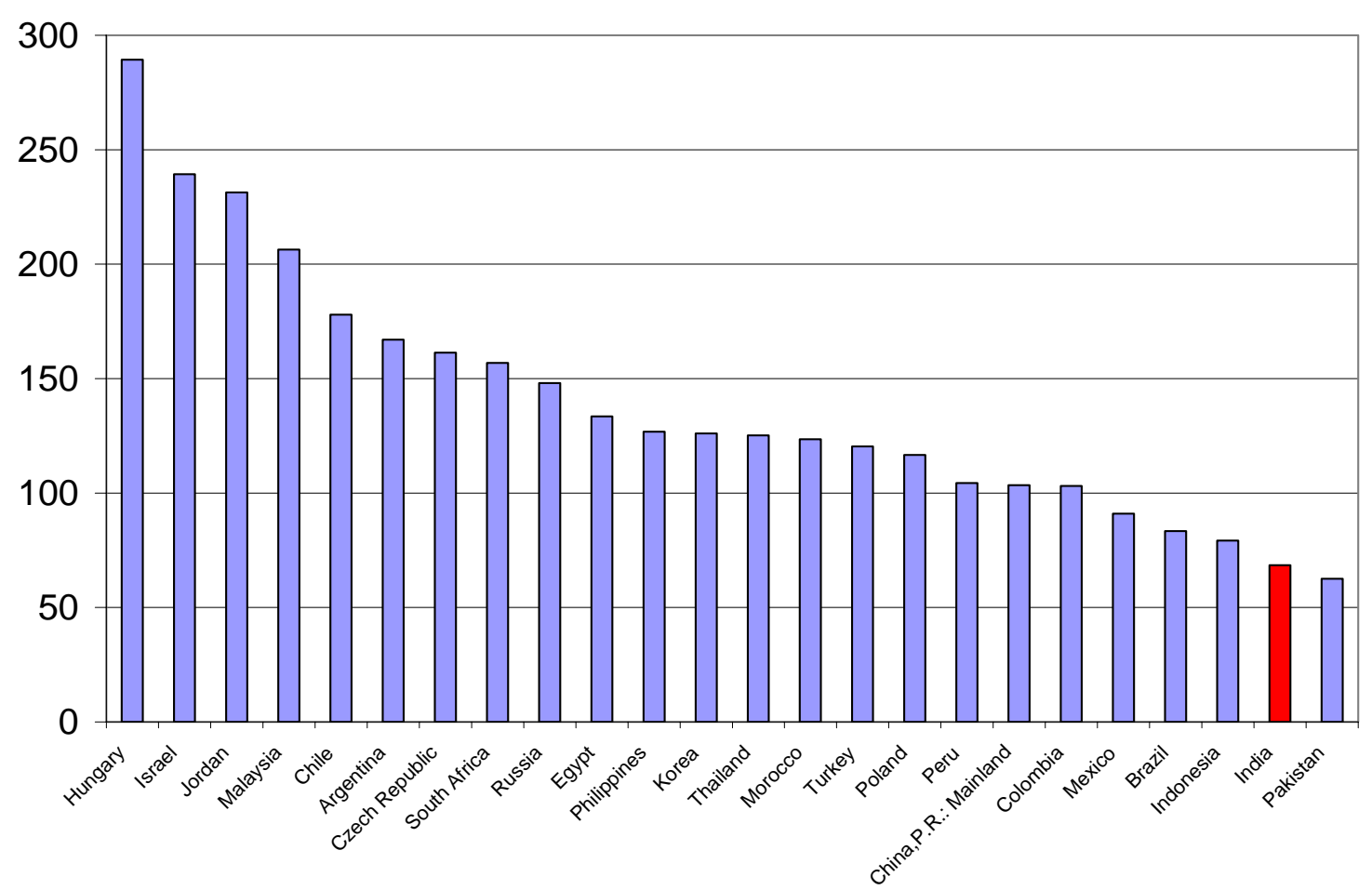

Source: Lane and Milesi-Ferretti (2006) dataset and author's calculations. 
Figure 3. Foreign Exchange Reserves: Flows and Stocks (in billions of U.S. dollars)

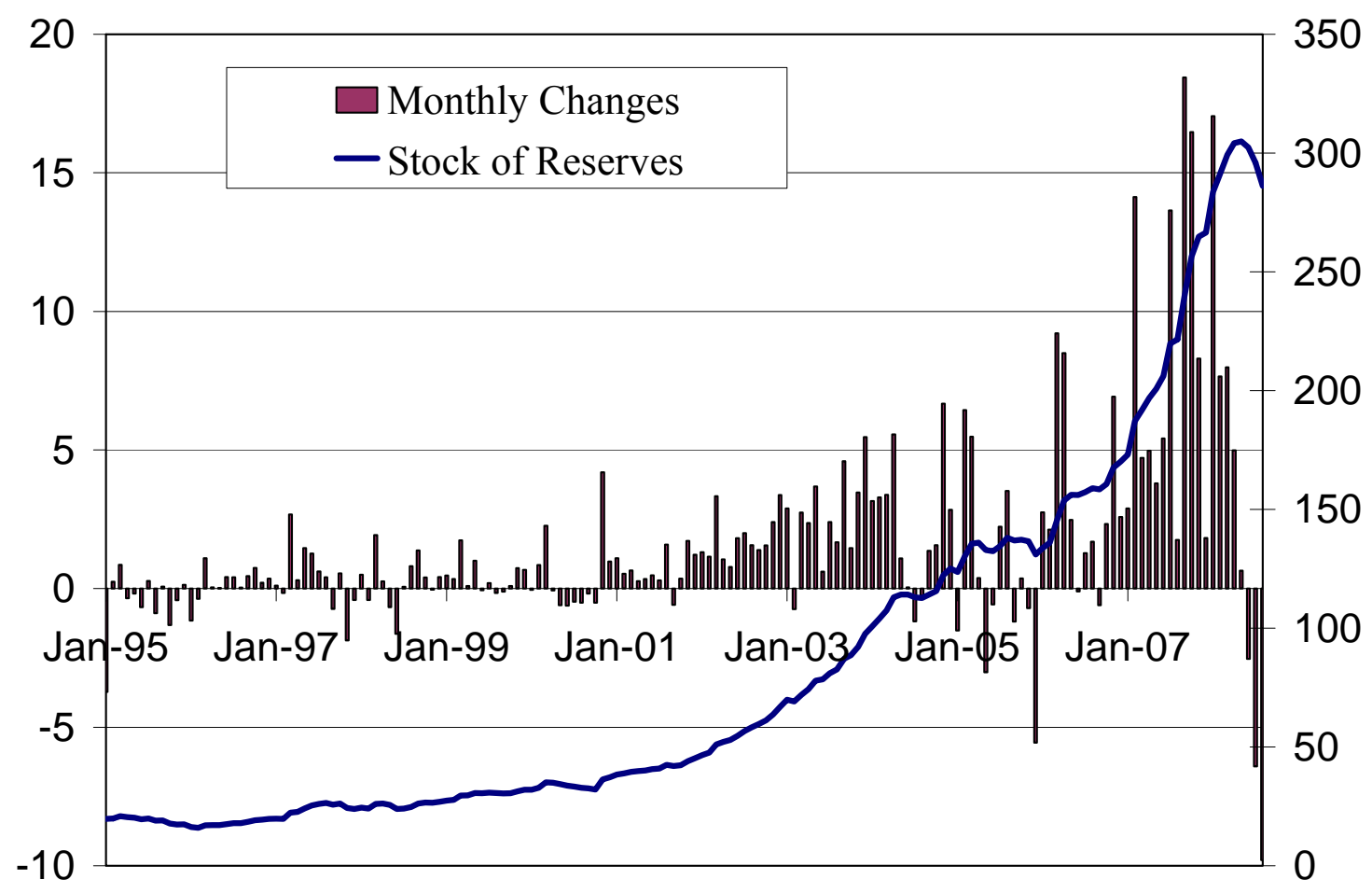

Note: The data in this figure go through August 2008.

Source: CEIC and author's calculations. 
Figure 4. Share of FDI and Portfolio Liabilities in Gross External Liabilities

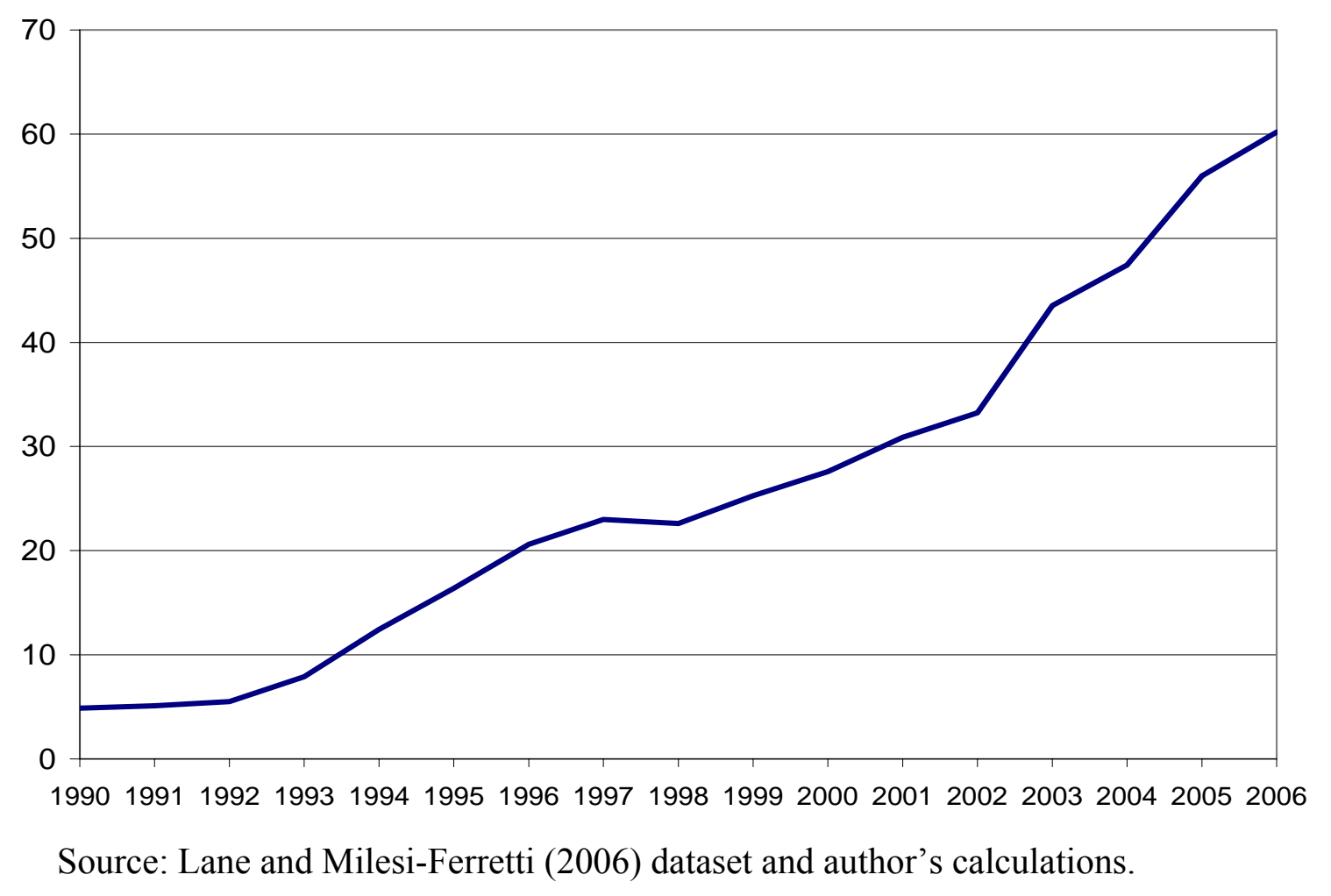


Figure 5. Ratio of FDI and Portfolio Liabilities to Gross External Liabilities: Emerging Markets

1995

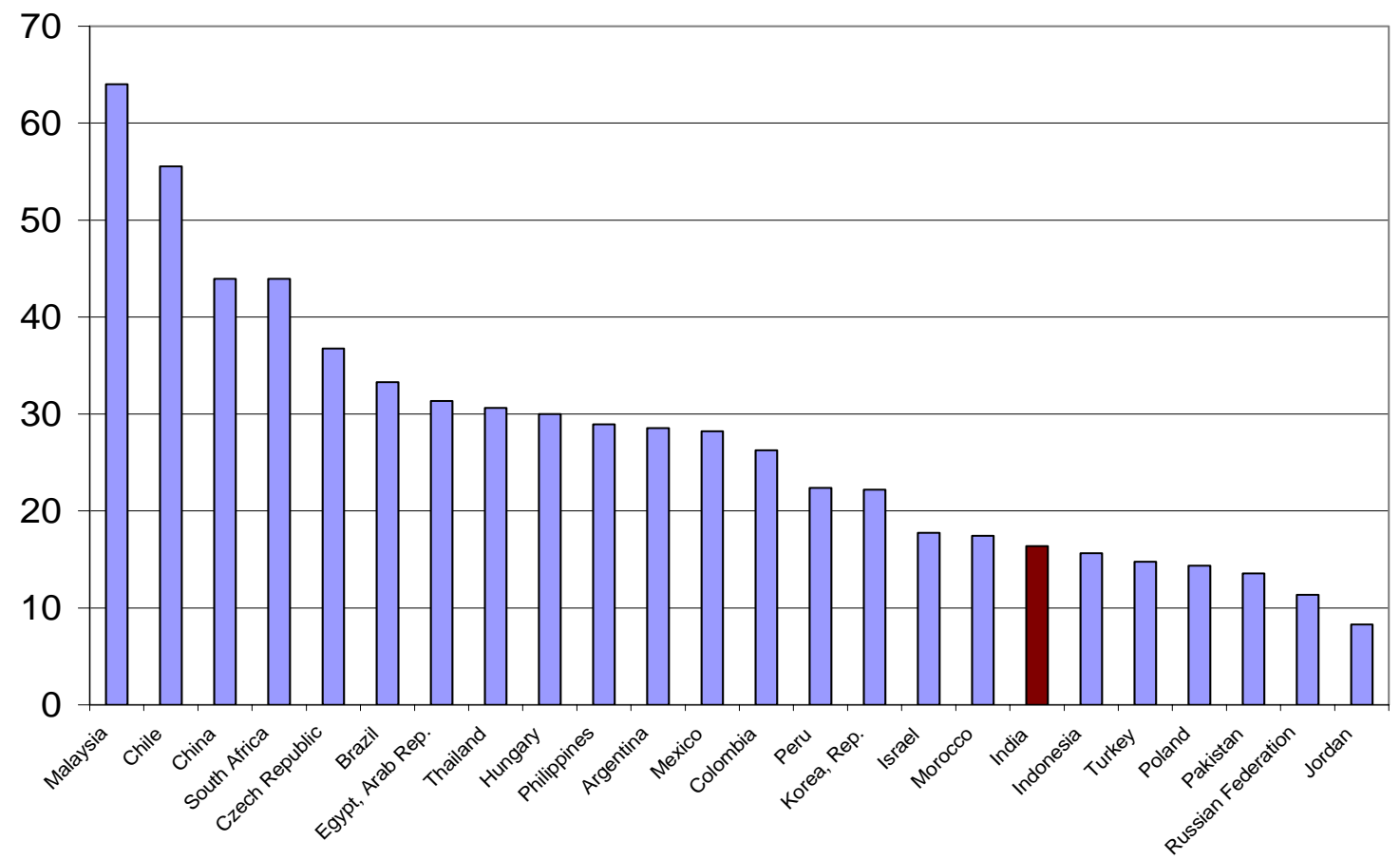

2006

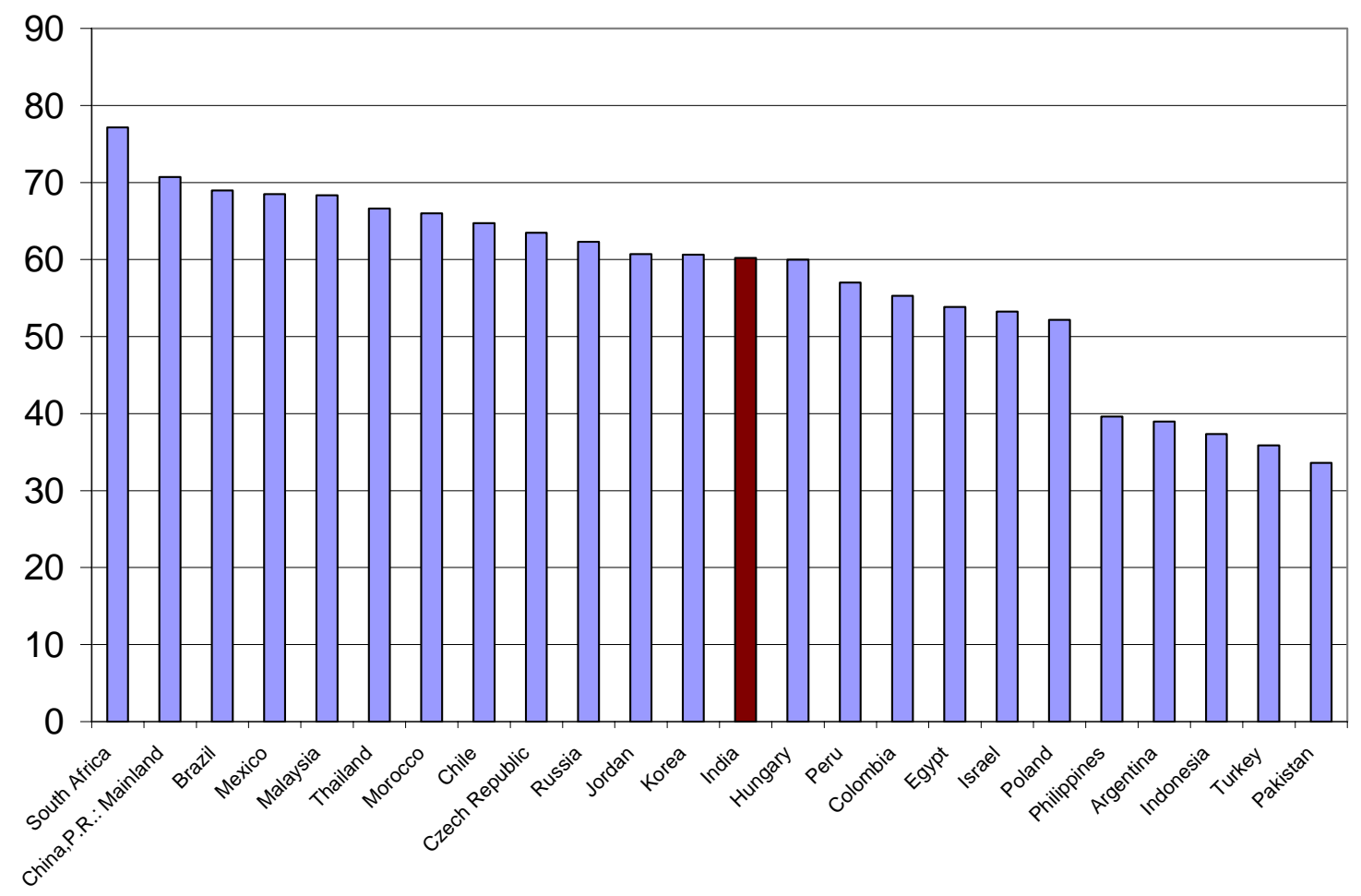

Source: Lane and Milesi-Ferretti (2006) dataset and author's calculations. 
Figure 6. The Savings-Investment Balance (in percent of GDP)

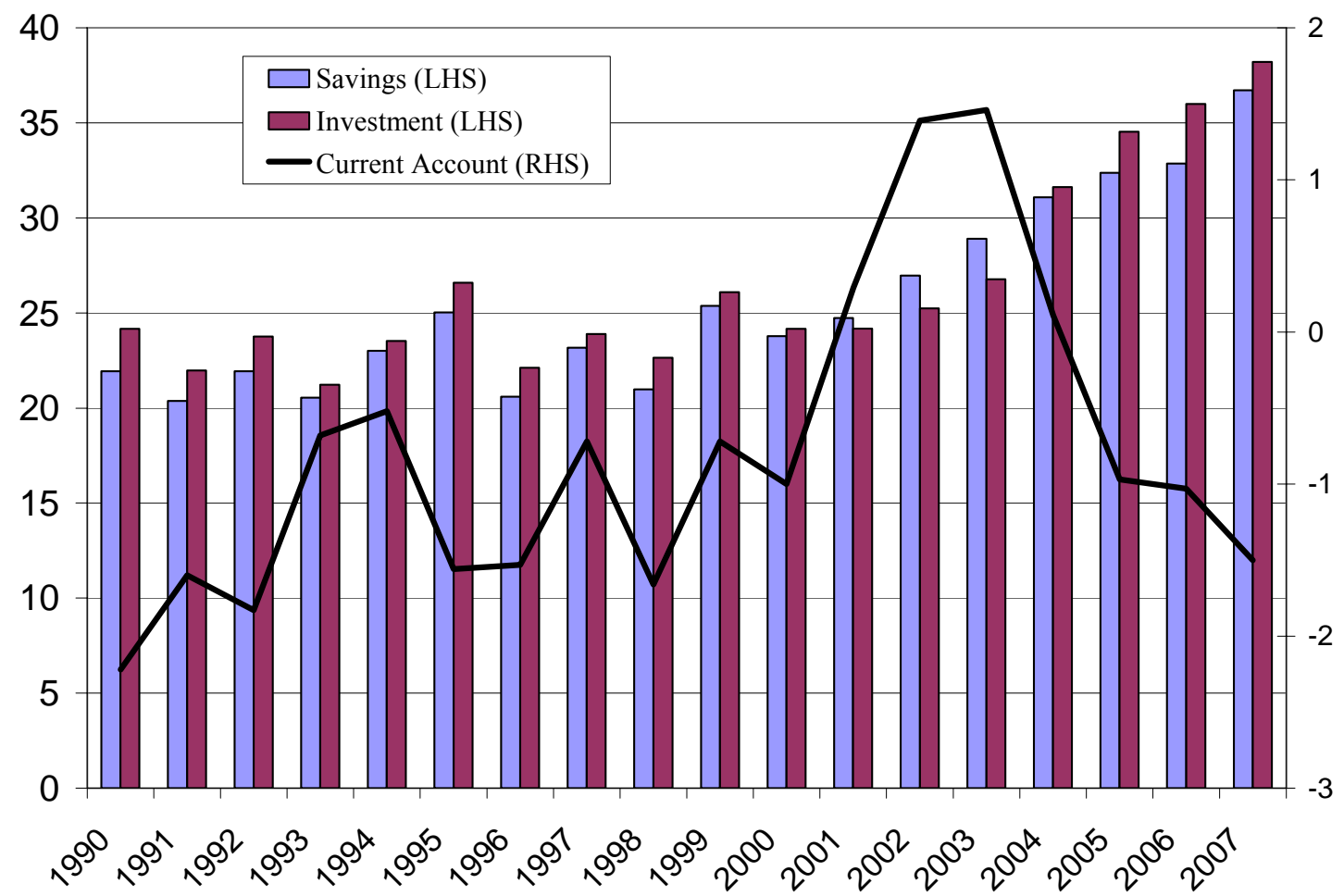

Source: World Development Indicators (World Bank) 
Figure 7. India's Share of Gross Inflows to and Outflows from Emerging Markets and Other Developing Countries

\section{India's Share of Gross Inflows}

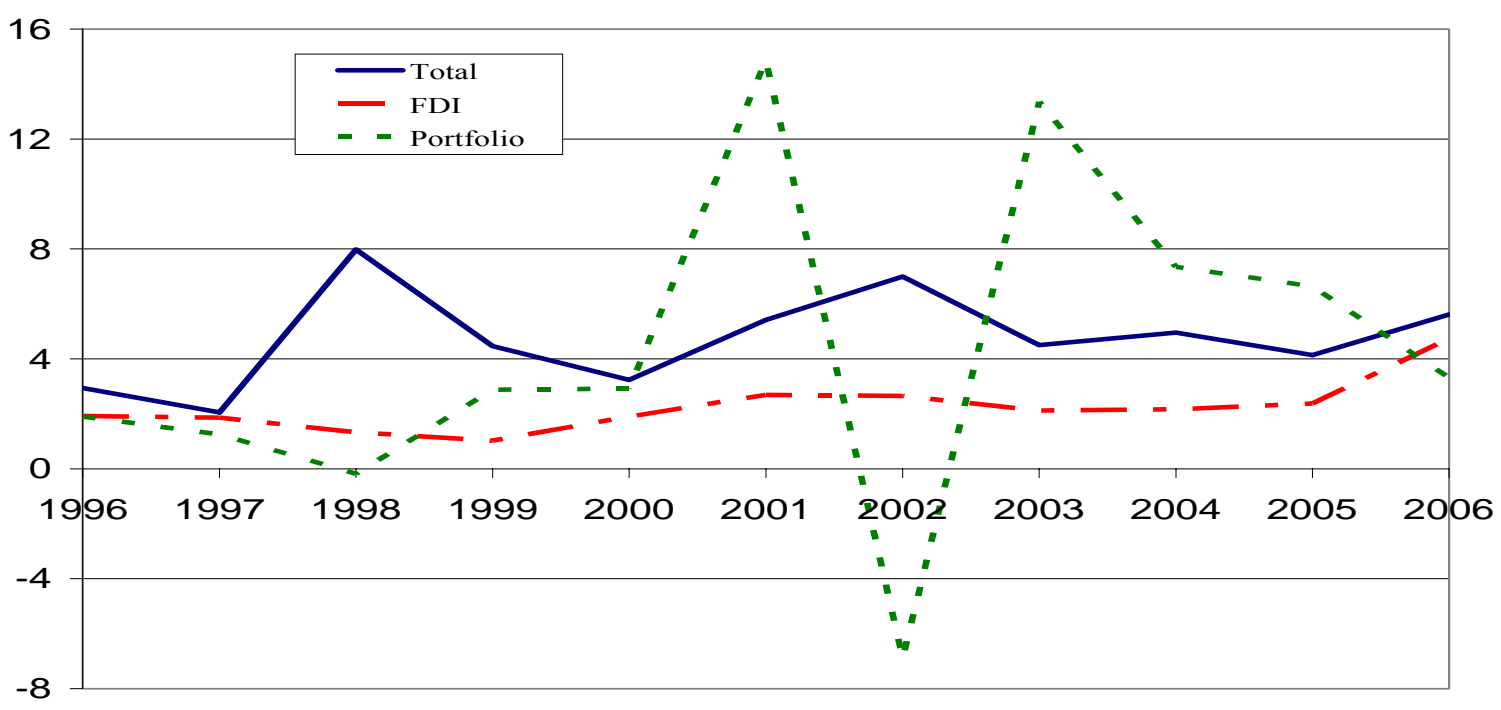

\section{India's Share of Gross Outflows}

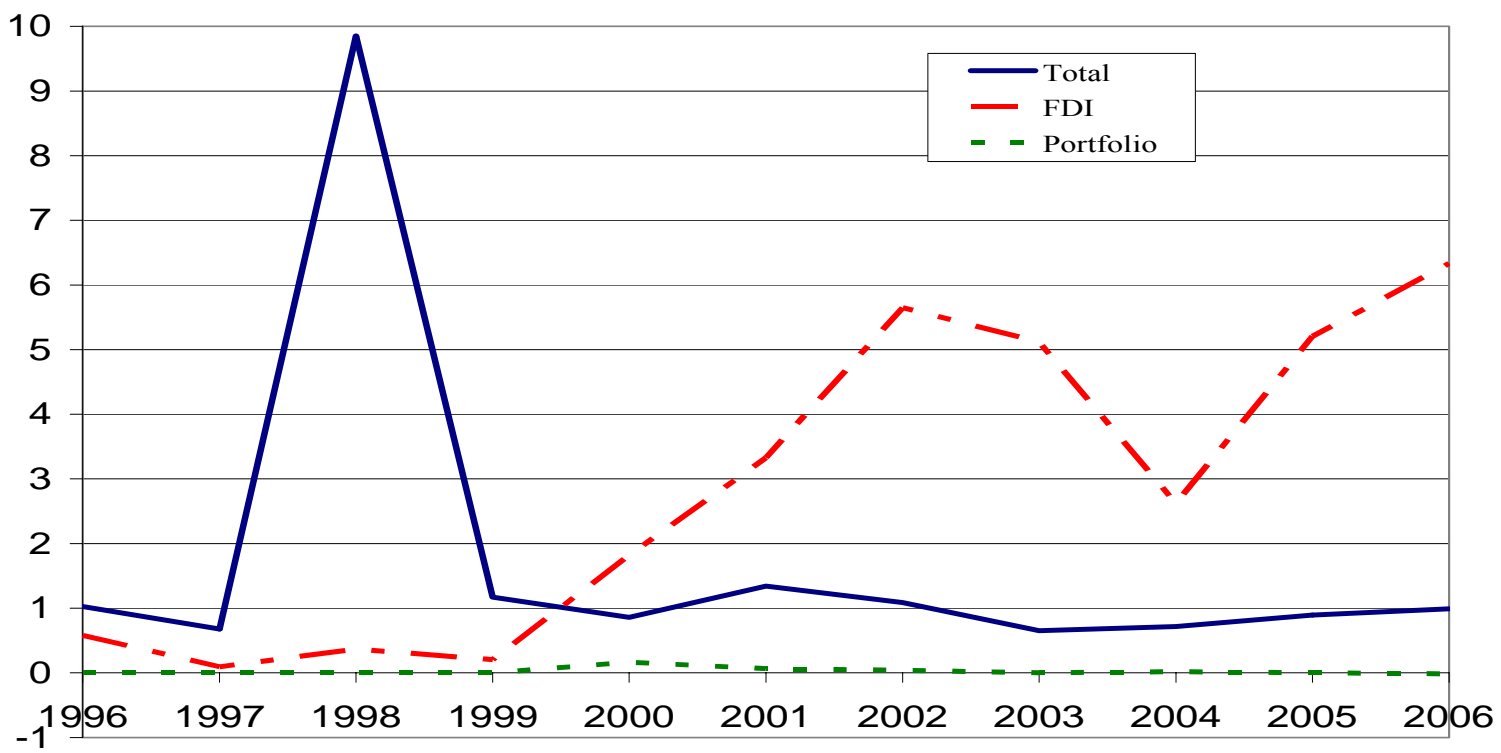

Note: The top panel shows the volume of gross inflows into India in specific categories of capital flows as a ratio of the corresponding total gross inflows into all emerging markets and other developing countries. The denominator includes flows amongst emerging markets and other developing countries since these are counted as part of gross inflows of the recipient countries. The bottom panel shows India's share of total gross outflows from all emerging markets and other developing countries (including to other countries within this group).

Source: CEIC, Global Financial Stability Report 2008 and author's calculations. 
Figure 8. Nominal Exchange Rate

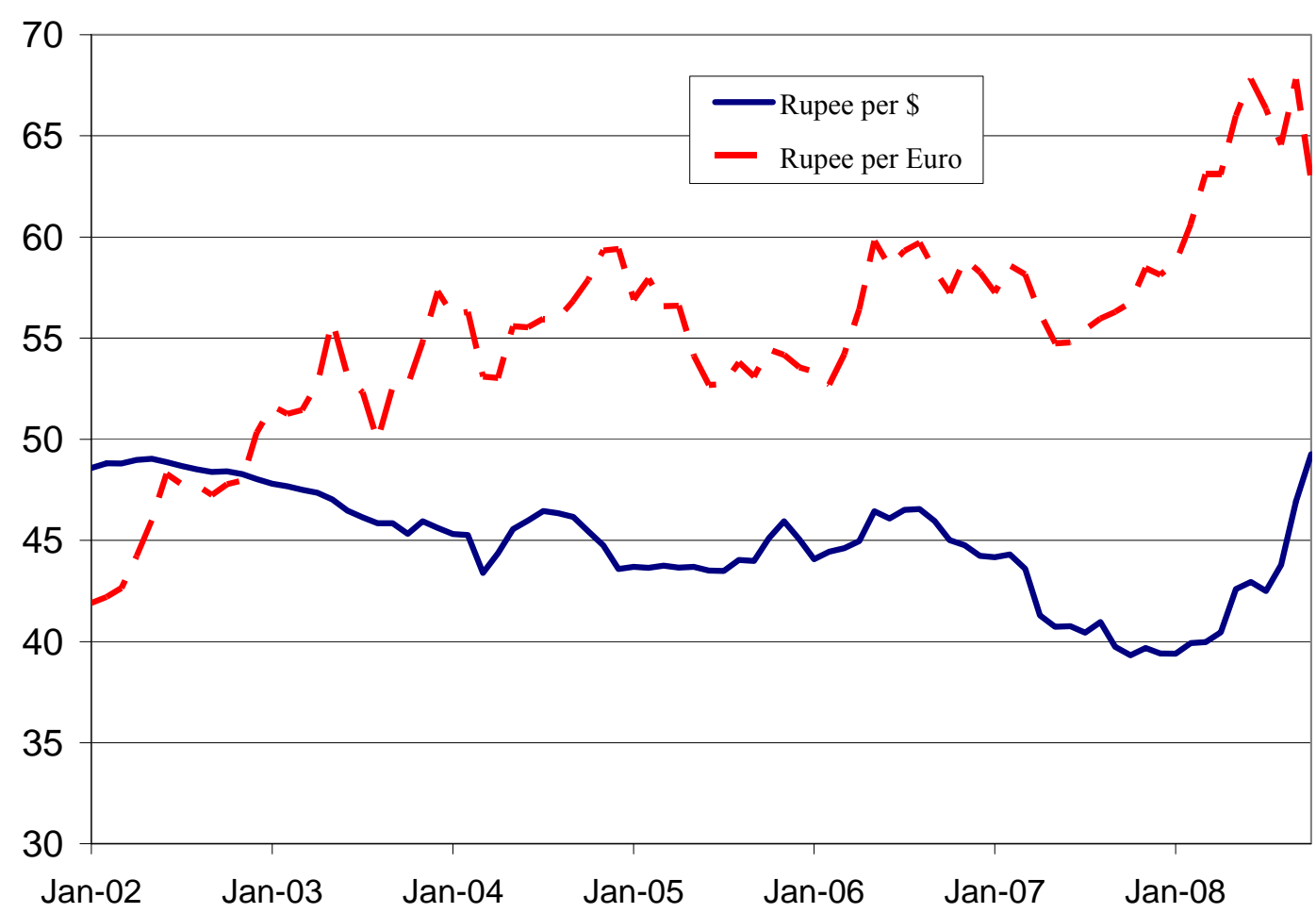

Note: The data in this figure are up to November 2008.

Source: CEIC. 
Figure 9. Real and Nominal Effective Exchange Rates

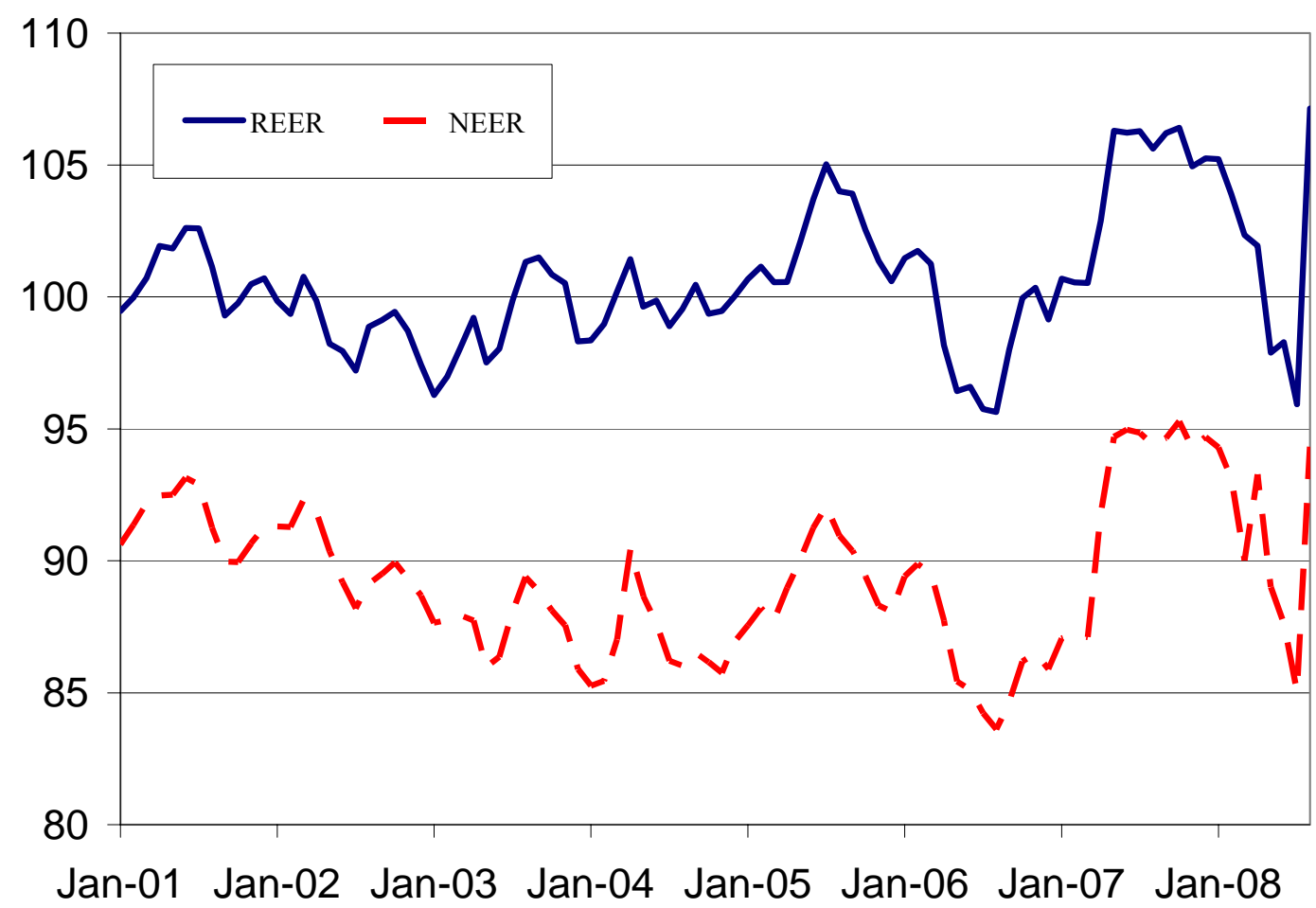

Notes: The effective exchange rates here are trade-weighted and measured against 36 currencies.

REER =100 (1993-94), NEER =100 (1993-94)

Source: CEIC 
Figure 10. Interest Rates in India Relative to U.S.

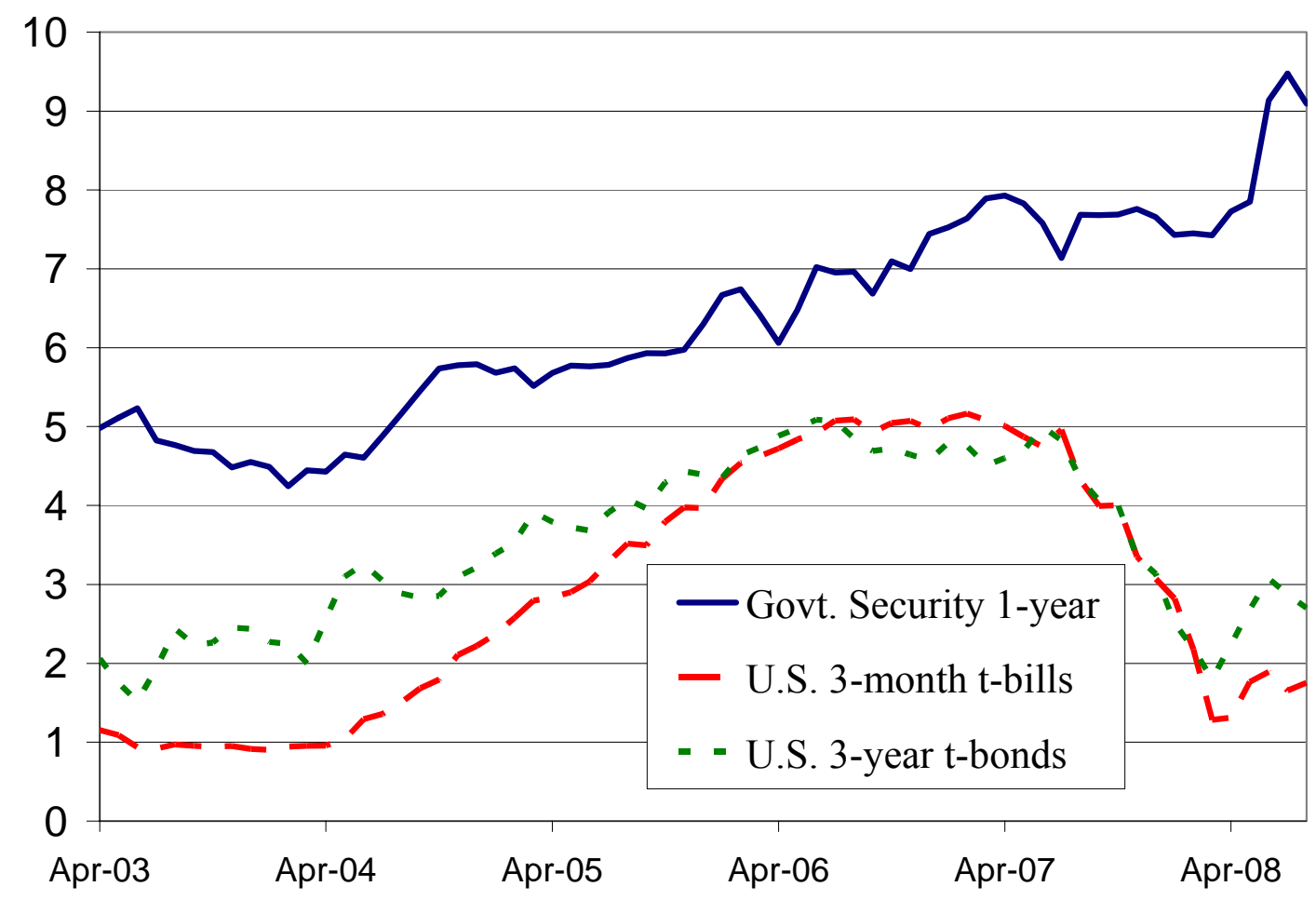

Note: The data in this figure go through August 2008.

Source: CEIC and author's calculations. 
Figure 11. Outstanding Stock of Market Stabilization Bonds (in billions of Indian rupees)

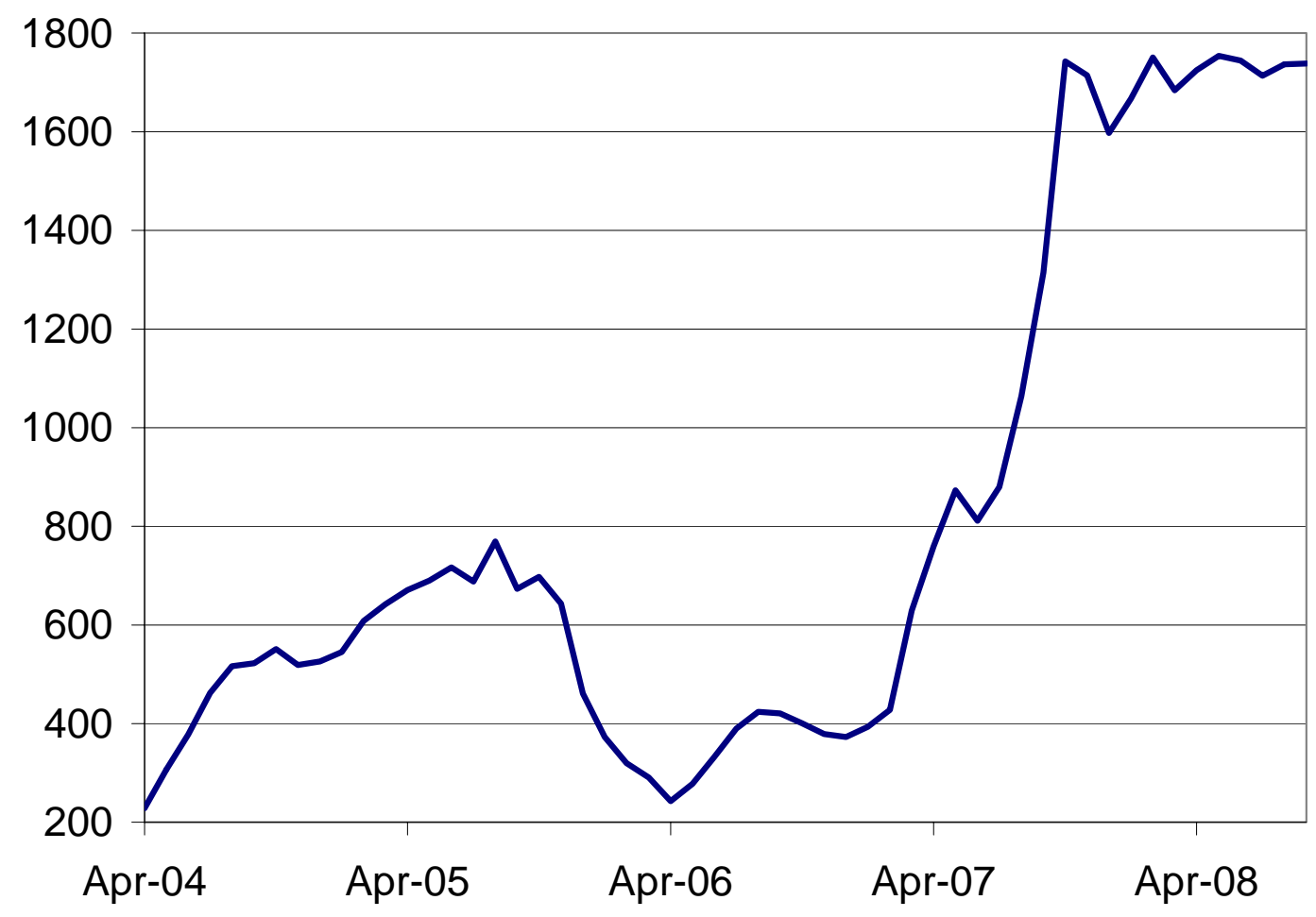

Source: CEIC 
Figure 12. Trade Openness Ratio

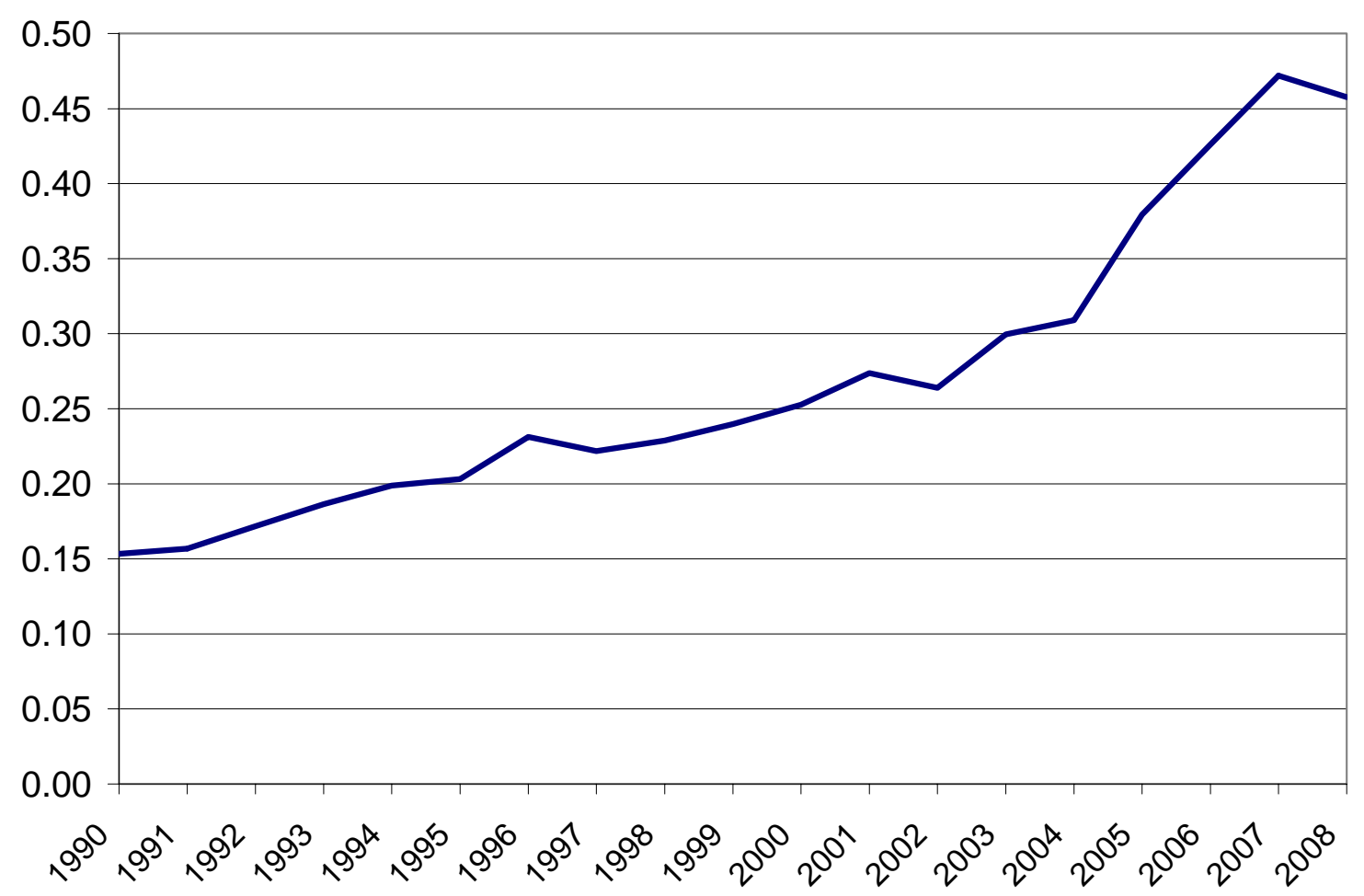

Note: This figure shows the sum of imports and exports of goods and services as a ratio to GDP.

Source: CEIC and authors' calculations. 